УДК 911.2:551.58

\title{
КЛИМАТИЧЕСКИЕ ИЗМЕНЕНИЯ КАК ФАКТОР ТРАНСФОРМАЦИИ РАСТИТЕЛЬНОГО ПОКРОВА НА ПРИМЕРЕ КАРАДАГСКОГО ЛАНДШАФТНО-ЭКОЛОГИЧЕСКОГО СТАЦИОНАРА*
}

\author{
Зуев А.В., Летухова В. Ю., Зуева Е.А.
}

Карадагская научная станция им. Т. И. Вяземского - природный заповедник РАН-филиал ФГБУН ФИЦ «Институт биологии южных морей имени А. О. Ковалевского РАН», пгт. Курортное, г. Феодосия, Российская Федераџия, e-mail:letukhova@gmail.com

В работе рассмотрено влияние быстро меняющихся климатических факторов на жизнеспособность отдельных видов растений в условиях Карадагского ландшафтноэкологического стационара. Отмечено, что за последние годы произошло значительное отклонение основных климатических показателей от средних многолетних значений: увеличились средняя годовая, минимальная и максимальная температуры воздуха, поверхности почвы и лесной подстилки, уменьшились годовое количество осадков и количество воды в почвенном слое. Все это, в свою очередь, повлекло за собой трансформацию растительного покрова, массовое усыхание отдельных видов деревьев и кустарников, исчезновение или уменьшение численности некоторых влаголюбивых лесных травянистых растений на территории Карадагского ландшафтно-экологического стационара. Определено, что из годовых поступлений атмосферной влаги, ноябрьские осадки оказывают наибольшее воздействие на устойчивость лесных фитоценозов. Установлено, что основной причиной нынешнего состояния растительности является катастрофическое понижение уровня грунтовых вод.

Ключевые слова: климат, температура, осадки, поверхностный сток, грунтовые воды, изменение лесорастительных условий, состояние растительности, Карадагский природный заповедник.

\section{Введение}

Карадагский ландшафтно-экологический стационар (КЛЭС) располагается в югозападной части Карадагского заповедника на юго-восточном склоне хребта Беш-Таш. Климат стационара, находящегося на высоте от 120 до 250,8 м н.у.м. и удаленного от Черного моря на 1,85 км, несколько более суровый, чем на Карадагской научноисследовательской геофизической обсерватории (КНИГО), расположенной на берегу моря (42 м н.у.м.), который ранее характеризовали как переходный от субсредиземноморского характерного для ЮБК к умерено континентальному умерено жаркому сухому, свойственному степной части крымского полуострова (Природа Карадага, 1989).

В последние годы в состоянии растительных сообществ стационара происходят отчасти противоречивые, но в целом тревожные изменения. С одной стороны, продолжается естественный процесс зарастания степных участков лесной и кустарниковой растительностью. Доминируют в наступлении на степь граб (Carpinus orientalis Mill.), фисташка (Pistacia mutica Fisch. et May.) и держи-дерево (Paliurus spinachristi Mill.). В тоже время наблюдается массовый отпад и ослабление некоторых видов деревьев и кустарников. Полностью выпали терновые (Pruneta spinosae) растительные группировки. Шиповник (Rosa corymbifera Borkh.) усох на 95\%. Выпали или находятся в угнетенном виде (от VI до II категорий состояния (Рожков, Козак, 1989)) большинство экземпляров клена (Acer campestre L.), ясеня (Fraxinus excelsior L.), боярышников (Crataegus orientalis Pall. ex Bieb., C. pojarkovae Kossych). Вблизи стационара полностью выпал карагач (Ulmus carpinifolia Rupp. ex Suckow) (VI-VII). А в течение всего

\footnotetext{
* Работа выполнена в рамках темы гос. задания № АААA-A19-119012490044-3.
} 
вегетационного сезона 2018 г. даже палиурусовые сообщества (Paliureta spinae-christi) были в ослабленном состоянии. Среди пушистодубовых насаждений много деревьев II и III категорий состояния.

Цель исселований: проанализировав многолетние ряды данных гидрометеорологических параметров КЛЭС, выявить причинно-следственные связи между динамикой климата и ее влиянием на состояние древесно-кустарниковой и травянистой растительности, а также установить иерархическую значимость климатических процессов (и их показателей), обусловивших изменение лесорастительных условий, приведших к негативным экологическим результатам.

\section{Материал и методы}

В основу работы положены гидрометеорологические наблюдения, проводимые на территории Карадагскогого заповедника за период 2000-2018 гг. Для анализа использованы многолетние данные проводимых на КЛЭС измерений: температура воздуха, температура поверхности почвы, температура лесной подстилки, количество осадков, задержание осадков кронами деревьев, влажность почвы и поверхностный сток. Гидрологические ряды были получены по результатам наблюдений за режимом грунтовых вод станций, расположенных неподалеку от КЛЭС: колодца в низовье склоновой балки гряды Беш-Таш и источника Чобан-Чокрак или Сюрю-Кая Южный $(\mathrm{C} / Ю)$ у южной оконечности хребта Сюрю-Кая. Кроме того, использовались наблюдения за режимом вод источника Левинсона-Лессинга (Л/Л). Показатели вычислялись путем элементарного осреднения данных.

Метеорологическая площадка стационара, на которой регулярно проводились измерения температуры воздуха в психрометрической будке и температуры поверхности почвы на открытом оголенном от растительности участке, расположена в нижней части водосбора на относительно ровной поверхности $\left(\mathrm{CB}\right.$, крутизна $\left.5^{\circ}\right)$ в 15 м от тальвега балки на высоте 140 м н.у.м.

Наблюдение за температурным режимом подстилки осуществлялось под пологом грабинниково-дубового лесного сообщества (8Дп2Гб ед.Кп), находящегося на прибалочном склоне восточной экспозиции крутизной $25^{\circ}$. Полнота насаждения 0,9 , высота древостоя до 10 м. В подлеске кизил (Cornus mas L.), изредка боярышник (Crataegus sp.). Травянистый покров редкий: чесночник черешчатый (Alliaria petiolata (Bieb.) Cavara et Grande), вздутосемянник корнубийский (Physospermum cornubiense (L.) DC.), бородавник средний (Lapsana intermedia Bieb.). Температура измерялась в полуперегнившем слое подстилки на глубине 3 см от ее поверхности.

Индекс континентальности рассчитывался по формуле Н.Н. Иванова (1953):

$$
K=(A / 0,33 \varphi) * 100 \% \text {, (от } 25 \text { до } 300 \text { ед.), }
$$

где $K$ - индекс континентальности; $A$ - годовая амплитуда температуры воздуха, ${ }^{\circ} \mathrm{C} ; \varphi$ - географическая широта.

Рядом с пунктами наблюдения за температурным режимом на открытом степном участке и под лесным пологом установлены сосуды для сбора осадков и лизиметры высотой 22,5 см, заполненные почвой с неизмененной структурой и в то же время свободной от непосредственного воздействия древесных корней. Площади приемных отверстий лизиметров и сосудов для сбора осадков между собой равны.

Индекс годового распределения осадков определялся по формуле:

$$
\text { Игхо }=(\text { Omn - Oxn }) / \text { Огод, }
$$

где $O m n, O x n$ и Огод суммы осадков за теплое и холодное полугодия и за год (Сергин и др., 2001). 
Наблюдения за поверхностным стоком проводились на стоковых площадках СП1 и СП-3, расположенных на некогда (на момент создания стационара в 1995 г.) открытом месте, а ныне зарастающими лесо- и шибляко-образующими древесно-кустарниковыми растениями на хорошо задернованных склонах балки.

СП-1 (площадь 15,5 м²) находится на правом северо-восточном склоне балки, крутизна склона 15․ В 1998 г. здесь находилась опушечная травянистая группировка, примыкающая к грабинниково-дубовому лесу. Господствовали ксеромезофильные злаки и разнотравье: мятлик узколистный, ежа сборная, осока шерстистая, дубровник обыкновенный, земляника, лабазник обыкновенный (Poa angustifolia L., Dactylis glomerata L., Carex tomentosa L., Teucrium chamaedrys L., Fragaria viridis Duch., Filipendula vulgaris Moench), присутствовали всходы и подрост граба (Carpinus orientalis Mill.). К 2018 г. это уже дубово-грабинниковый молодняк (6Гб4Дп, полнота 0,7) с подростом тех же пород, травянистый ярус сильно разрежен (покрытие не более 25\%), в качестве доминантов здесь выступают типчак и эгонихон (Festuca valesiaca Gaudin и Aegonichon purpureo-caeruleum (L.) Holub), также присутствует лишайник (Cladonia sp.). В последние два года большую часть СП-1 покрывает лесная подстилка.

СП-3 (площадь 25,5 м²) установлена на противоположном (левом) юго-восточном склоне балки крутизной $14^{\circ}$, покрытом травянистой растительностью с участием кустарников. В 1998 г. это эфемерно-грудницево-сухоцветно-типчаковая степь окруженная кустарниками. Подрост: держи-дерево, груша лохолистная (Paliurus spinachristi Mill, Pyrus elaeagrifolia Pall); густой травянистый покров: типчак, сухоцвет цилиндрический, грудница, синеголовник полевой, василек солонский, эгилопс, лук прочноодетый (Festuca valesiaca Gaudin, Xeranthemum cylindraceum Sibth. et Smith, Galatella villosa (L.) Reichenb., Eryngium campestre L., Centaurea salonitana Vis., Aegilops biuncialis Vis., Allium firmotunicatum Fomin.). В 2018 г. - смешанная кустарниковостепная группировка: кустарниковый ярус образован держи-деревом (Paliurus spinachristi Mill), покрытие 25\%; в травянистом ярусе доминируют житняк гребенчатый, бородач кровоостанавливающий, грудница мохнатая (Agropyron pectinatum (Bieb.) Beauv., Bothriochloa ischaemum (L.) Keng, Galatella villosa (L.) Reichenb).

Для определения полевой влажности почвы пробы отбирались в 30 точках стационара (Ландшафтно-экологический ..., 1999), распределенных по 5 растительным группировкам на глубине 5-10 см. К настоящему времени состав и структура наблюдаемых растительных сообществ претерпела значительные изменения вплоть до смены степных на кустарниковые (точки 1, 2, 9, 13, 25) и лесные (точки 5, 23). В марте 2017 года добавлено три новых мест отбора проб (точка № 32 - формация клена полевого, точка №33 - степное сообщество, точка №34 - фисташковое редколесье).

Определение влажности производилось методом прямых весовых измерений (термовесовым методом). Расчет влажности проводился по формуле:

$$
W=(\sigma-8) /(6-a) * 100 \%,
$$

где $a$ - масса бюкса, г; $\sigma$ - масса бюкса с сырой почвой, г; в - масса бюкса с абсолютно сухой почвой, г; (б - в) - масса воды, г; (в - a) - масса сухой почвы, г.

Гидротермический коэффициент Селянинова (ГТК) (показатель увлажнённости территории) определялся как:

$$
\Gamma T K=\sum r /\left(0,1 \sum t\right),
$$

где $\sum r$ - сумма осадков (мм) за рассматриваемый период календарного года (месяц, вегетационный период) со среднесуточными температурами выше $10^{\circ} \mathrm{C} ; \sum t-$ сумма активных температур выше $10^{\circ} \mathrm{C}$ (CAT) за тот же период календарного года.

Колодец, используемый в качестве пункта наблюдений за грунтовыми водами, расположен на днище балки в 300 м от КЛЭС и в 2,25 км севернее Карадагской научной 
станции на высоте около 140 м н.у.м. Грунтовые воды вскрыты шахтой колодца в пролювиальных щебенистых суглинках у контакта их с глинами на глубине около 4 метров от поверхности. Областью питания грунтовых вод является верхняя часть Карадагской балки, которая на 70\% покрыта лесом.

Источник С/Ю расположен неподалёку от КЛЭС на склоне балки Карадагской на южном склоне хребта Сюрю-Кая в 2,75 км к северу от Карадагской научной станции на высоте 250 м н.у.м. В питании источника участвуют воды атмосферных осадков и трещинно-карстовые воды прилегающей части хребта. Склон у источника сложен четвертичными коллювиальными и делювиальными щебнисто-суглинистыми карбонатными отложениями, залегающими на водоупорных юрских глинах. Кленоводубовые насаждения, растущие на склоне, как и возвышающийся над ними известняковый массив способствуют быстрому проникновению атмосферной влаги до водонепроницаемых глинистых пластов.

Источник Л/Л, за режимом вод которого наблюдения ведутся с марта 2007 г., расположен в нижней части одноименной скалы, сложенной из туфа, расположенной у берега моря в 1 км к востоку от Карадагской научной станции. Источник постоянный, нисходящий, образован трещинно-грунтовыми водами, водоупором которых служит монолитный нетрещиноватый лавовый поток спилитов, питается в основном за счет инфильтрации атмосферных осадков.

Гидрологические наблюдения проводились с периодичностью раз в неделю и сразу после выпадения атмосферных осадков. Отслеживалась также суточная динамика параметров исследуемых объектов.

\section{Результаты и обсуждение}

В температурном режиме стационара 2012-2018 гг. относительно периода 20002011 гг. произошли следующие изменения: среднесуточная температура воздуха на КЛЭС повысилась на $0,8^{\circ} \mathrm{C}$. Максимальный ее рост $\left(\right.$ на $\left.1,8^{\circ} \mathrm{C}\right)$ наблюдался в мае. Лишь в октябре и ноябре температура воздуха оказалось прохладней на $0,1^{\circ} \mathrm{C}$ и $0,3^{\circ} \mathrm{C}$ соответственно (табл.1). Среднегодовые суточные минимальные значения температуры воздуха выросли на $0,7^{\circ} \mathrm{C}$. Наибольшее увеличение среднемесячных суточных минимальных величин (на $1,7^{\circ} \mathrm{C}$ ) произошло в мае. В ноябре они совпали. Незначительные (на 0,3 и $0,1^{\circ} \mathrm{C}$ ) понижения суточных минимумов наблюдались в октябре и декабре. Среднемесячные суточные температурные максимумы, которые в среднем за год повысились на $0,8^{\circ} \mathrm{C}$ (более всего на $1,7^{\circ} \mathrm{C}$ в апреле и мае), стали ниже в октябре и ноябре. Произошло небольшое увеличение амплитуды колебания температуры воздуха. Средняя годовая амплитуда температуры воздуха (разность средних месячных температур самого теплого и самого холодного месяца (август-январь) стала на Карадагском стационаре более континентальной на $1,1^{\circ} \mathrm{C}$, и составила $23,4^{\circ} \mathrm{C}$. Амплитуда, вычисленная из фактических ежегодных среднемесячных величин самого теплого и самого холодного месяца (которые иногда приходились не только на август и январь, но и на другие летние и зимние месяцы), оказалась больше на $0,1^{\circ} \mathrm{C}$ и составила $24,8^{\circ}$ C. По формуле Н.Н. Иванова индекс континентальности в первом случае увеличился с 150 до 157, а во втором с 166 до 167 единиц. Амплитуда колебания температуры воздуха по среднемесячным величинам суточных абсолютных температурных значений в среднем за год увеличилась на $0,1^{\circ} \mathrm{C}$. Длительность безморозного периода на стационаре увеличилась с 307 до 316 дней. Количество дней с температурой, превышающей биологический минимум для развития растений в $5,0^{\circ} \mathrm{C}$, изменилось с 284 до 291. Период активной вегетации, когда среднесуточная температура была выше $10^{\circ} \mathrm{C}$, составлял в 2000-2011 гг. - 207, а в 2012-2018 гг. уже 212 дней. Сумма среднесуточных температур воздуха более $10,0^{\circ} \mathrm{C}$ (САТ) изменилась с 3870,8 до 
$4131,6^{\circ} \mathrm{C}$, что больше порогового значения, принятого для субтропического климата $\left(4000^{\circ} \mathrm{C}\right)$. Число дней с температурой $30,0^{\circ} \mathrm{C}$ и более возросло с 29 до 40 дней. Произошли заметные сдвиги климатических сезонов (смещение сроков и изменение продолжительности). Метеорологическая зима стала наступать на 10 дней раньше (в среднем с 30 декабря), при этом ее продолжительность сократилось с 38 до 34 дней. Среднесуточная температура воздуха за климатический зимний сезон повысилась всего на $0,1^{\circ} \mathrm{C}$ и составила минус $1,4^{\circ} \mathrm{C}$ (за календарную зиму температура воздуха возросла на $0,4^{\circ} \mathrm{C}$ и в среднем за 2012-2018 гг. равнялась плюс 2,9 $\left.{ }^{\circ} \mathrm{C}\right)$. Метеорологический весенний сезон увеличился с 87 до 89 дней. Температура воздуха при этом поднялась с 7,7 до $8,1^{\circ} \mathrm{C}$ (за календарную весну с 10,3 до $11,7^{\circ} \mathrm{C}$ ). Более всего увеличилась продолжительность метеорологического лета, количество дней которого изменилось с 150 до 155 дней, а температура воздуха с 21,1 до $22,0^{\circ} \mathrm{C}$ (у календарного летнего сезона с 22,8 до 24,0 ${ }^{\circ} \mathrm{C}$ ). Климатическая осень уменьшилась с 91 до 88 дней. Ее температура воздуха повысилась с 7,5 до $7,8^{\circ} \mathrm{C}$ (у календарной осени с 13,2 до $13,3^{\circ} \mathrm{C}$ ).

Таблица 1.

Среднемесячные значения температуры воздуха на КЛЭС в 2000-2018 гг.

\begin{tabular}{|c|c|c|c|c|c|c|c|c|c|c|c|c|}
\hline \multirow[b]{2}{*}{ Месяц } & \multicolumn{3}{|c|}{ Минимальная } & \multicolumn{3}{|c|}{ Максимальная } & \multicolumn{3}{|c|}{ Среднесуточная } & \multicolumn{3}{|c|}{ Макс - Мин. } \\
\hline & $\begin{array}{l}\bar{\Xi} \\
\stackrel{N}{1} \\
\stackrel{\sim}{0}\end{array}$ & 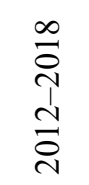 & 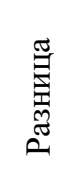 & 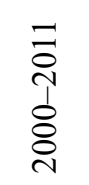 & $\begin{array}{l}\infty \\
\stackrel{\infty}{1} \\
\stackrel{\sim}{\sim} \\
\stackrel{\sim}{\sim}\end{array}$ & 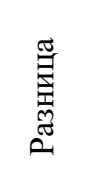 & 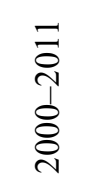 & $\begin{array}{l}\stackrel{\infty}{\stackrel{\sim}{\Lambda}} \\
\stackrel{\sim}{\sim} \\
\stackrel{\sim}{\sim}\end{array}$ & 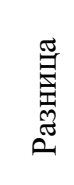 & 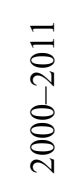 & $\begin{array}{l}\infty \\
\stackrel{\infty}{\sigma} \\
\stackrel{1}{\sim} \\
\stackrel{\sim}{\sim}\end{array}$ & 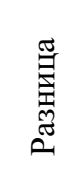 \\
\hline 1 & $-1,2$ & $-0,8$ & $-0,4$ & 4,6 & 5,2 & $-0,5$ & 1,7 & 2,2 & $-0,5$ & 5,8 & 6,0 & $-0,2$ \\
\hline 2 & $-1,1$ & $-0,3$ & $-0,8$ & 5,3 & 5,6 & $-0,4$ & 2,0 & 2,5 & $-0,5$ & 6,3 & 5,9 & 0,4 \\
\hline 3 & 1,6 & 2,6 & $-1,0$ & 8,8 & 9,9 & $-1,1$ & 5,0 & 6,2 & $-1,2$ & 7,2 & 7,3 & $-0,1$ \\
\hline 4 & 6,2 & 6,8 & $-0,6$ & 14,2 & 15,9 & $-1,7$ & 10,1 & 11,4 & $-1,2$ & 8,0 & 9,2 & $-1,1$ \\
\hline 5 & 11,0 & 12,7 & $-1,7$ & 20,1 & 21,9 & $-1,7$ & 15,6 & 17,4 & $-1,8$ & 9,1 & 9,2 & 0,0 \\
\hline 6 & 15,5 & 17,1 & $-1,5$ & 24,9 & 26,4 & $-1,5$ & 20,4 & 21,9 & $-1,5$ & 9,3 & 9,3 & 0,1 \\
\hline 7 & 19,1 & 19,8 & $-0,7$ & 28,8 & 29,2 & $-0,3$ & 24,1 & 24,6 & $-0,5$ & 9,7 & 9,4 & 0,3 \\
\hline 8 & 19,3 & 20,9 & $-1,6$ & 29,0 & 30,6 & $-1,6$ & 24,0 & 25,5 & $-1,5$ & 9,7 & 9,8 & $-0,1$ \\
\hline 9 & 14,6 & 15,1 & $-0,5$ & 23,5 & 24,3 & $-0,9$ & 18,8 & 19,5 & $-0,7$ & 8,9 & 9,2 & $-0,3$ \\
\hline 10 & 9,5 & 9,2 & 0,3 & 16,9 & 16,7 & 0,2 & 12,9 & 12,7 & 0,1 & 7,4 & 7,5 & $-0,2$ \\
\hline 11 & 4,9 & 4,9 & 0,0 & 11,7 & 11,0 & 0,7 & 8,1 & 7,8 & 0,3 & 6,8 & 6,1 & 0,7 \\
\hline 12 & 1,0 & 0,8 & 0,1 & 6,5 & 7,1 & $-0,6$ & 3,8 & 3,9 & $-0,1$ & 5,6 & 6,3 & $-0,7$ \\
\hline Сред. & 8,4 & 9,1 & $-0,7$ & 16,2 & 17,0 & $-0,8$ & 12,2 & 13,0 & $-0,8$ & 7,8 & 7,9 & $-0,1$ \\
\hline Зима & $-0,4$ & $-0,1$ & $-0,3$ & 5,5 & 6,0 & $-0,5$ & 2,5 & 2,9 & $-0,4$ & 5,9 & 6,1 & $-0,2$ \\
\hline Весна & 6,3 & 7,4 & $-1,1$ & 14,4 & 15,9 & $-1,5$ & 10,3 & 11,7 & $-1,4$ & 8,1 & 8,5 & $-0,4$ \\
\hline Лето & 18,0 & 19,2 & $-1,3$ & 27,6 & 28,7 & $-1,2$ & 22,8 & 24,0 & $-1,2$ & 9,6 & 9,5 & 0,1 \\
\hline Осень & 9,6 & 9,7 & $-0,1$ & 17,3 & 17,3 & 0,0 & 13,2 & 13,3 & $-0,1$ & 7,7 & 7,6 & 0,1 \\
\hline \multicolumn{10}{|c|}{$\begin{array}{l}\text { Годовая амплитуда по среднемноголетним среднемесячным температурам } \\
\text { (август - январь) }\end{array}$} & 22,3 & 23,4 & $-1,1$ \\
\hline \multicolumn{10}{|c|}{ Годовая амплитуда (средняя из фактических ежегодных) } & 24,7 & 24,8 & $-0,1$ \\
\hline
\end{tabular}

Тенденция к повышению температуры воздуха сохраняется. За последние три года (2016-2018 гг.) среднесуточная температура воздуха на КЛЭС оказалась выше своего среднего многолетнего значения (2000-2015 гг.) на 0,6² C. При этом в июле она совпала, в январе и ноябре была ниже, а в остальные месяцы оказалась выше средней многолетней величины. 2018 г. стал самым теплым $\left(13,6^{\circ} \mathrm{C}\right)$ за весь период исследования. Месячные минимальные значения температуры воздуха превышали многолетние абсолютные минимумы. Шестнадцатого февраля 2016 года максимальная температура воздуха $\left(23,9^{\circ} \mathrm{C}\right)$ оказалась на $7,4^{\circ} \mathrm{C}$ выше абсолютной февральской зарегистрированной 29 февраля 2004 г. Максимальная температура воздуха $\left(38,5^{\circ} \mathrm{C}\right)$, отмеченная 8 августа 2017 г., была близка к абсолютному температурному максимуму $\left(38,9^{\circ} \mathrm{C}\right)$, зарегистрированному 8 августа 2010 г. 
Минимальная и максимальная годовая температура воздуха, поверхности почвы и лесной подстилки существенно изменилась (табл. 2). Среднегодовая минимальная температура возросла: воздуха на $0,9^{\circ} \mathrm{C}$, поверхности почвы на $1,1^{\circ} \mathrm{C}$. В лесной подстилке из-за понижения ее минимальных температурных значений в зимние месяцы и в октябре она осталась прежней. Увеличение среднего годового температурного максимума произошло во всех наблюдаемых средах. В особенности возросла максимальная температура лесной подстилки в теплое и жаркое время (в среднем с апреля по сентябрь на $2,1^{\circ} \mathrm{C}$ ), что свидетельствует о снижении защитной роли лесного полога, который из-за дефицита атмосферной влаги был вынужден уменьшить свою листовую поверхность, увеличив доступ солнечной радиации. О том, что кроны деревьев в 2012-2018 гг. стали более ажурными, говорит и сокращение температурных различий. Разница между минимальными температурами подстилки и воздуха сократилась на $0,8^{\circ} \mathrm{C}$, подстилки и поверхности почвы - на $1,1^{\circ} \mathrm{C}$. Сокращение среднегодового различия максимума подстилки к максимам воздуха и земной поверхности составило $0,5^{\circ} \mathrm{C}$.

Таблица 2.

Средние значения по недельным показателям температурного режима воздуха, поверхности почвы и лесной подстилки за период с 2000-2018 гт.

\begin{tabular}{|c|c|c|c|c|c|c|c|c|c|c|}
\hline \multirow[b]{2}{*}{$\begin{array}{c}\text { Мес } \\
\text { яЦ }\end{array}$} & \multicolumn{2}{|c|}{ В будке } & \multicolumn{2}{|c|}{$\begin{array}{c}\text { На поверхности } \\
\text { почвы }\end{array}$} & \multicolumn{2}{|c|}{$\begin{array}{c}\text { В подстилке в } \\
\text { лесу }\end{array}$} & \multicolumn{2}{|c|}{$\begin{array}{c}\text { Разница мин. } \\
\text { температур }\end{array}$} & \multicolumn{2}{|c|}{$\begin{array}{l}\text { Разница макс. } \\
\text { температур }\end{array}$} \\
\hline & $\sum^{ \pm}$ & 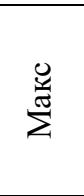 & $\sum^{\mathrm{I}}$ & 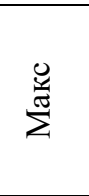 & $\sum^{\mathrm{I}}$ & 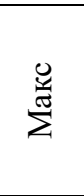 & 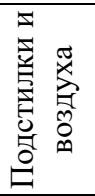 & 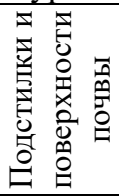 & 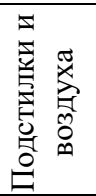 & 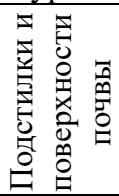 \\
\hline \multicolumn{11}{|c|}{ Данные измерений температурного режима 2000-2011 гг. } \\
\hline 1 & $-5,3$ & 9,2 & $-5,9$ & 11,2 & 0,6 & 5,7 & 5,9 & 6,5 & $-3,5$ & $-5,6$ \\
\hline 2 & $-5,2$ & 9,9 & $-5,8$ & 15,1 & 0,5 & 5,8 & 5,6 & 6,2 & $-4,2$ & $-9,4$ \\
\hline 3 & $-2,1$ & 13,2 & $-4,1$ & 25,5 & 2,0 & 8,5 & 4,1 & 6,0 & $-4,7$ & $-17,0$ \\
\hline 4 & 2,8 & 17,9 & 0,2 & 37,8 & 5,9 & 13,1 & 3,1 & 5,7 & $-4,8$ & $-24,7$ \\
\hline 5 & 7,7 & 23,4 & 5,6 & 50,6 & 11,2 & 16,1 & 3,5 & 5,6 & $-7,3$ & $-34,5$ \\
\hline 6 & 12,4 & 27,7 & 11,5 & 57,5 & 15,3 & 19,8 & 2,9 & 3,8 & $-7,9$ & $-37,6$ \\
\hline 7 & 16,0 & 31,0 & 14,6 & 59,9 & 18,3 & 22,4 & 2,3 & 3,7 & $-8,6$ & $-37,5$ \\
\hline 8 & 17,0 & 32,5 & 15,3 & 58,4 & 19,2 & 24,1 & 2,2 & 3,9 & $-8,4$ & $-34,3$ \\
\hline 9 & 12,3 & 27,5 & 9,5 & 46,7 & 15,7 & 20,9 & 3,4 & 6,2 & $-6,6$ & $-25,7$ \\
\hline 10 & 6,7 & 22,1 & 5,6 & 33,7 & 10,8 & 16,7 & 4,1 & 5,2 & $-5,4$ & $-16,9$ \\
\hline 11 & 1,6 & 16,4 & $-0,5$ & 20,8 & 6,0 & 12,1 & 4,4 & 6,4 & $-4,3$ & $-8,8$ \\
\hline 12 & $-2,4$ & 11,2 & $-3,7$ & 13,3 & 3,0 & 8,3 & 5,4 & 6,7 & $-2,9$ & $-5,0$ \\
\hline Ср. год. & 5,1 & 20,2 & 3,5 & 35,9 & 9,1 & 14,5 & 3,9 & 5,5 & $-5,7$ & $-21,5$ \\
\hline \multicolumn{11}{|c|}{ Данные измерений температурного режима 2012-2018 гг. } \\
\hline 1 & $-4,4$ & 9,9 & $-4,8$ & 12,1 & 0,2 & 7,0 & 4,7 & 5,0 & $-2,8$ & $-5,1$ \\
\hline 2 & $-4,5$ & 10,4 & $-3,8$ & 15,0 & 0,1 & 6,4 & 4,5 & 3,8 & $-4,1$ & $-8,6$ \\
\hline 3 & $-0,7$ & 14,2 & $-2,0$ & 26,1 & 2,5 & 9,2 & 3,2 & 4,6 & $-5,0$ & $-16,9$ \\
\hline 4 & 2,9 & 19,5 & 1,2 & 41,6 & 6,4 & 14,8 & 3,5 & 5,2 & $-4,7$ & $-26,8$ \\
\hline 5 & 9,6 & 25,1 & 8,0 & 52,3 & 12,6 & 18,5 & 3,1 & 4,6 & $-6,6$ & $-33,8$ \\
\hline 6 & 14,1 & 29,0 & 13,2 & 55,7 & 15,9 & 21,9 & 1,7 & 2,6 & $-7,1$ & $-33,8$ \\
\hline 7 & 16,8 & 32,2 & 15,9 & 60,5 & 18,3 & 24,7 & 1,5 & 2,4 & $-7,5$ & $-35,7$ \\
\hline 8 & 18,4 & 33,4 & 16,6 & 60,0 & 19,7 & 26,3 & 1,3 & 3,1 & $-7,1$ & $-33,7$ \\
\hline 9 & 13,4 & 29,0 & 11,4 & 50,0 & 15,8 & 22,6 & 2,4 & 4,4 & $-6,4$ & $-27,3$ \\
\hline 10 & 6,3 & 21,4 & 3,6 & 33,1 & 9,3 & 17,0 & 3,0 & 5,7 & $-4,4$ & $-16,1$ \\
\hline 11 & 2,7 & 16,0 & $-0,1$ & 21,3 & 6,1 & 12,6 & 3,4 & 6,2 & $-3,4$ & $-8,6$ \\
\hline 12 & $-2,4$ & 12,0 & $-3,5$ & 14,1 & 2,1 & 9,0 & 4,4 & 5,5 & $-3,1$ & $-5,1$ \\
\hline Ср. год. & 6,0 & 21,0 & 4,6 & 36,8 & 9,1 & 15,8 & 3,1 & 4,4 & $-5,2$ & $-21,0$ \\
\hline
\end{tabular}

Примечание: Надо учитывать, что среднегодовые температурные минимумы, вычисленные из суточных минимальных температур, будут на $3,2^{\circ} \mathrm{C}$ выше, чем рассчитанные из недельных минимальных значений, а средние максимальные годовые, взятые из суточных максимальных температурных показателей, окажутся на 4,0 $\mathrm{C}$ ниже полученных из недельных максимальных. 
В среднем за 2012-2018 гг. на КЛЭС годовое количество осадков уменьшилось по сравнению с периодом 2000-2011 гг. с 500,5 до 466,8 мм (табл. 3). При этом наблюдалось внутригодовое их перераспределение. Среднее количество осадков оказалось больше в январе и с мая по июль. Во все другие месяцы года атмосферной влаги стало меньше. Такое изменение в распределении количества осадков с тенденцией к летнему увлажнению наблюдается с 2010 г. Это связано, прежде всего, с увеличением объема летних ливневых осадков, причем не за счет увеличения количества дождливых дней, которых, напротив, с апреля по сентябрь (теплое полугодие) сократилось с 35 до 32, а за счет увеличения поступлений влаги за дождь. В результате индекс годового распределения осадков (Игхо) изменился на КЛЭС с минус 0,126 до плюс 0,070. Самым сухим за 2012-2018 гг. выдался 2012 г.: на стационаре выпало 349,7 мм атмосферной влаги, что в 1,3 раза меньше средней многолетней величины. За эти годы самым влажным был 2016 г:: на КЛЭС выпало 618,7 мм осадков, что в 1,3 раза больше среднего многолетнего значения.

Таблица 3.

Поступление осадков за 2000-2018 гг.

\begin{tabular}{|c|c|c|c|c|c|c|c|c|c|}
\hline \multirow[b]{2}{*}{ Месяц } & \multicolumn{3}{|c|}{ Среднее } & \multicolumn{3}{|c|}{ Минимальное } & \multicolumn{3}{|c|}{ Максимальное } \\
\hline & 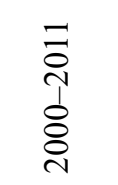 & 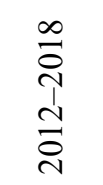 & 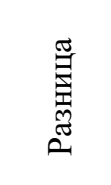 & 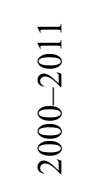 & $\begin{array}{l}\infty \\
\stackrel{\infty}{\sigma} \\
\stackrel{1}{d} \\
\stackrel{\sim}{\sigma}\end{array}$ & 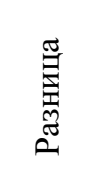 & 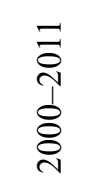 & $\begin{array}{l}\stackrel{\infty}{\circ} \\
\stackrel{\sim}{1} \\
\stackrel{\sim}{\sim} \\
\stackrel{\sim}{\sim}\end{array}$ & 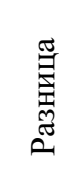 \\
\hline 1 & 39,4 & 51,5 & $-12,1$ & 13,1 & 32,0 & $-18,9$ & 106,4 & 69,3 & 37,1 \\
\hline 2 & 42,5 & 31,1 & 11,4 & 3,8 & 15,0 & $-11,3$ & 94,5 & 63,2 & 31,3 \\
\hline 3 & 45,1 & 32,3 & 12,7 & 5,5 & 11,3 & $-5,8$ & 113,8 & 63,9 & 49,9 \\
\hline 4 & 28,8 & 18,5 & 10,4 & 0,0 & 3,2 & $-3,2$ & 59,8 & 39,7 & 20,1 \\
\hline 5 & 29,0 & 39,2 & $-10,2$ & 2,2 & 4,5 & $-2,3$ & 63,2 & 122,1 & $-58,9$ \\
\hline 6 & 42,3 & 91,8 & $-49,5$ & 2,7 & 24,3 & $-21,6$ & 130,7 & 212,3 & $-81,6$ \\
\hline 7 & 28,5 & 36,8 & $-8,3$ & 0,0 & 1,9 & $-1,9$ & 67,0 & 85,2 & $-18,2$ \\
\hline 8 & 43,7 & 27,8 & 15,9 & 0,0 & 0,3 & $-0,3$ & 173,1 & 76,8 & 96,3 \\
\hline 9 & 46,5 & 35,7 & 10,8 & 5,4 & 1,5 & 3,9 & 134,1 & 99,5 & 34,6 \\
\hline 10 & 52,0 & 38,2 & 13,8 & 5,6 & 9,7 & $-4,1$ & 133,1 & 80,8 & 52,3 \\
\hline 11 & 59,4 & 26,7 & 32,7 & 1,1 & 9,1 & $-8,0$ & 137,4 & 45,7 & 91,7 \\
\hline 12 & 43,3 & 37,2 & 6,1 & 3,8 & 5,8 & $-2,0$ & 115,5 & 86,5 & 29,0 \\
\hline Год & 500,5 & 466,8 & 33,7 & 308,3 & 349,7 & $-41,4$ & 714,5 & 618,7 & 95,8 \\
\hline $4-9$ & 218,8 & 249,8 & $-31,0$ & & & & & & \\
\hline $1-3,10-12$ & 281,7 & 217,0 & 64,7 & & & & & & \\
\hline Игхо: & $-0,126$ & 0,070 & $-0,196$ & & & & & & \\
\hline
\end{tabular}

В кронах наблюдаемого грабинниково-дубового леса может задерживаться до $100 \%$ атмосферных осадков. Перехват осадков древесными кронами максимален в вегетационный период. Зимой твердые осадки, как правило, почти не задерживаются. Но иногда в результате ветрового переноса под кронами леса количество твердых осадков бывает заметно меньшим, чем в степи. Количество проникшей под древесный полог влаги зависит не только от времени года, но и от величины и интенсивности осадков. Часто осадки небольшой величины полностью расходуются на смачивание крон деревьев и испаряются, не достигнув поверхности почвы. Благодаря этому период без дождей оказывается более продолжительным под лесом, чем вне его. Зимняя форма дуба пушистого способна удерживать атмосферную влагу облиственными кронами большую часть года. Очень слабые (до 1 мм) жидкие осадки более всего проникают сквозь лесной полог в начале метеорологической весны, когда окончательно осыпается прошлогодняя листва. Выпадающие в жидкой форме осадки как в условиях степного сообщества, так и под пологом леса достаточно быстро проходят сквозь наблюдаемый слой почвы. На открытый степной участок поступает больше осадков, поэтому здесь наблюдается 
большее изменение веса почвы как при поступлении, так и при потере влаги. Минимум содержания почвенной влаги, как правило, под древесным пологом фиксируется позднее, чем в степи. После засухи в начале наступления времени, когда осадки начинают выпадать сравнительно часто и достаточно обильно, наблюдается как в степи, так и под пологом леса быстрое и значительное насыщение влагой почвы. При этом вес задерживающейся в почве лизиметров влаги составляет более $80 \%$ от веса выпавших осадков. По мере насыщения количество влаги, задерживающейся после очередного выпадения осадков в наблюдаемой толще почвы, уменьшается.

За 2012-2018 гг. кроны деревьев удержали в себе 21,9\% выпавших осадков, что на 10,9\% меньше, чем за период 2000-2011 гг. (табл. 4). Причем задержание влаги пологом леса уменьшилось при всех градациях осадков. Более свободное проникновение атмосферной влаги связано с состоянием древесной растительности, обусловленным продолжительными засухами и понижением уровня грунтовых вод. Растения, реагируя на повышение температурного режима и недостаток влаги, были вынуждены для снижения транспирации уменьшить свою листовую поверхность.

Таблица 4.

Перехват осадков древесными кронами в 2000-2018 гг.

\begin{tabular}{|c|c|c|c|c|c|c|}
\hline \multirow[b]{2}{*}{ Период } & \multirow[b]{2}{*}{$\begin{array}{c}\text { Градация } \\
\text { осадков }\end{array}$} & \multirow[b]{2}{*}{$\begin{array}{c}\text { Число } \\
\text { случаев }\end{array}$} & \multicolumn{2}{|c|}{ Осадки, мм } & \multicolumn{2}{|c|}{ Задержано кронами } \\
\hline & & & В лесу & $\begin{array}{c}\text { На степном } \\
\text { участке }\end{array}$ & MM & $\%$ \\
\hline \multirow{7}{*}{ 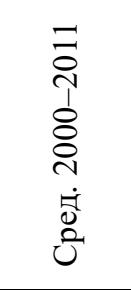 } & $0,1-1,0$ & 28 & 3,7 & 16,1 & 12,3 & 76,7 \\
\hline & $1,1-2,0$ & 15 & 9,4 & 23,5 & 14,1 & 60,3 \\
\hline & $2,1-5,0$ & 19 & 33,7 & 66,7 & 33,0 & 49,2 \\
\hline & $5,1-10,0$ & 13 & 63,9 & 96,7 & 32,7 & 34,2 \\
\hline & $10,1-20,0$ & 9 & 87,5 & 119,0 & 31,5 & 26,7 \\
\hline & Более 20,0 & 6 & 140,6 & 178,7 & 38,1 & 21,6 \\
\hline & Итого & 89 & 338,8 & 500,5 & 161,8 & 32,8 \\
\hline \multirow{7}{*}{ 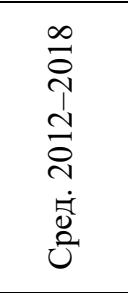 } & $0,1-1,0$ & 30 & 5,7 & 15,8 & 10,2 & 65,4 \\
\hline & $1,1-2,0$ & 13 & 10,4 & 19,9 & 9,5 & 47,9 \\
\hline & $2,1-5,0$ & 19 & 39,2 & 62,6 & 23,4 & 37,8 \\
\hline & $5,1-10,0$ & 12 & 64,8 & 87,0 & 22,3 & 25,7 \\
\hline & $10,1-20,0$ & 7 & 76,0 & 93,0 & 17,0 & 19,8 \\
\hline & Более 20,0 & 6 & 170,9 & 188,5 & 17,6 & 9,8 \\
\hline & Итого & 86 & 366,8 & 466,8 & 100,0 & 21,9 \\
\hline
\end{tabular}

\section{Дефицит атмосферной влаги в наиболее значимое для развития растительности время года.}

С начала второй декады марта 2012 г. (Зуев, 2012) в степном и лесном сообществах наблюдаемый почвенный горизонт стал активно утрачивать влагу. Лишь в конце марта (с 28 марта) а затем и в начале апреля выпавшие небольшой величины (до 5,8 мм) осадки ненамного и ненадолго увеличивали вес почвенного слоя. Большую часть апреля, первые две декады мая в исследуемой толщи почвы влага убывала. В степи, пока там почва была еще относительно влажной, процесс потери почвенной влаги шел быстрей и в большем объеме. К концу засушливого периода более влажная лесная почва теряла влаги даже несколько больше, чем степная. Самый сухой период в 2012 году пришелся на сентябрьоктябрь. За сентябрь выпало всего 1,5 мм осадков, не сумевших осилить лесные кроны. Почва лизиметров активно теряла запас влаги. В результате в степи месячный водный баланс почвы оказался самым отрицательным за год. В октябре первые осадки (1,9 мм) поступили 19 октября. Накануне, в степном и лесном сообществах зафиксирован минимальный годовой вес лизиметров (4,297 и 3,720 кг.). Всего за календарную осень 2012 г. поступило лишь 31,2 мм, что на 126,7 мм меньше средней многолетней величины.

В марте 2013 г. (Зуев, 2013; Летухова, 2013) выпало 26,2 мм (в 1,7 раз меньше среднего мартовского количества) осадков. Наблюдаемый слой почвы в степи имел 
отрицательный месячный водный баланс. Два последних весенних месяца выдались аномально сухими. В апреле поступило 3,2 мм атмосферных осадков (из них кроны леса удержали 58,3\%), что в 9,1 раз меньше среднего для апреля. Почти весь май дождей не было. Наблюдаемый почвенный горизонт активно терял влагу. Лишь в середине третьей декады мая прошло два дождя (24 мая - 0,7 мм, 25 мая - 3,8 мм), количество которых оказалось в 6,5 раза меньше среднего майского. Продолжительный период с дефицитом атмосферной влаги не только не позволил нормально развиться и сформироваться многим видам травянистой растительности (которая уродилась аномально низкопродуктивной, а некоторые виды вообще не зацвели), но и не позволил нормально сформироваться побегам и листовым пластинкам у большинства древеснокустарниковой растительности. Начало июня выдалось дождливым. Только за два дня (3 и 4 июня) поступило в 1,3 раза больше среднемесячного для июня количества. Сразу после поступления влаги увеличение веса степного лизиметра оказалось почти равно весу осадков. А в лесу вес почвы оказался в 1,8 раз меньше веса поступившей атмосферной влаги. Всего же за первую декаду июня (в основном за три дождя - 3, 4 и 8 июня) выпало почти две средней июньской величины атмосферных осадков. Большая часть $(87,2 \%)$ из них не задержалась в кронах деревьев. Прошедшие 16-17 июня еще более обильные и интенсивные осадки почти все (98\%) миновали лесные кроны. При этом в лесной почве зафиксировано максимальное за год количество почвенной влаги. В итоге прошедшие невероятно обильные июньские осадки (наибольшие для этого месяца за все годы наблюдений) не только способствовали второй вегетации растительности (что для многих видов, в частности для дуба, вполне типично), но и позволили усыхающим от засухи деревьям выжить, сформировав из спящих почек новые побеги. Однако наиболее ослабленной кустарниковой растительности оправится не удалось. Произошло массовое усыхание шиповника и терна.

Февраль 2014 г. (Зуев, 2014; Летухова, 2014) оказался сухим - поступило 15,0 мм осадков, что на 25,1 мм меньше среднего количества за последние четырнадцать лет. Кроны леса задержали 29,7\%. В марте преобладала сухая и теплая погода. За семь дней с осадками поступило 11,3 мм, что в 3,9 раза меньше среднего для этого месяца количества. Кроны леса преодолело всего 56,2\%. В лесу убывание почвенной влаги происходило заметно медленнее. В апреле засуха продолжилась. В три дождливых дня выпало 12,2 мм (в 2,2 раза меньше средней апрельской величины). Из них лесные кроны задержали в себе 46,7\%. В мае до конца второй его декады атмосферной влаги также было мало. Наблюдаемый почвенный горизонт продолжал обезвоживаться. Восемнадцатого-девятнадцатого мая прошел мелкий, не интенсивный дождь (10,3 мм), после которого в лесу вес почвы лизиметра увеличился на величину веса проникших под полог осадков. А на степном участке оказался всего лишь на $24 \%$ меньше массы поступивших осадков. В целом же за май осадков поступило в 1,9 раз меньше обычного (среднего) количества для этого месяца. Июль 2014 г. был типично сухим - поступило 5,9 мм осадков (в 4 раза менее средней июльской величины), лесные кроны смогло преодолеть 2,4 мм (40,7\%). Почва лизиметров потеряла много влаги, количественно больше в степи. В августе было всего два дождя, за которые поступило 10,7 мм атмосферной влаги (в 4,1 раз меньше среднего августовского с 2000 г.), из них кроны леса смогло преодолеть 3,9 мм (36,4\%).

Большинство дней мая 2015 г. (Зуев, 2015) были очень сухими. С начала месяца по 27 мая выпало всего 2,8 мм осадков, которые почти полностью удержали собой выросшие на кронах деревьев листья. В сухом (всего 3 дождя, в сумме 1,9 мм - в 14,7 раз меньше нормы) и жарком $\left(24,1^{\circ} \mathrm{C}\right)$ июле 2015 г. кроны деревьев леса перехватили все поступившие осадки. Наблюдаемый слой почвы в лесном и степном сообществах активно обезвоживался. Почти полные две декады августа были очень сухими. Небольшой (2,0 мм) дождь, прошедший 5 августа, почти весь удержали древесные 
кроны. В степи вес лизиметра увеличился почти на величину веса поступивших дождевых вод. В лесу же наблюдаемый слой почвы продолжал терять влагу. Из 18,5 мм осадков, выпавших 18 августа, кроны леса преодолело 82,7\%. Вес почвы лесного лизиметра увеличился на величину веса проникшей под лесной полог атмосферной влаги. В степи наблюдаемый почвенный горизонт удержал в себе влаги несколько меньше веса поступивших осадков. Всего же за август за два дождливых дня поступило 20,5 мм осадков, что в 2,0 раза меньше средней многолетней августовской величины. Сентябрь был очень сухим (суше за годы наблюдений на стационаре был лишь сентябрь 2012 г.). За три дня с дождями (7, 8 и 14 сентября) поступило 3,9 мм, что в 11,2 раз меньше среднего сентябрьского многолетнего значения. Кроны деревьев пропустили часть влаги $(17,9 \%)$ только одного дождя. Почва лизиметров продолжала терять влагу.

Наиболее сухими месяцами во влажном 2016 г. (Зуев, 2016; Летухова, 2016) были март, апрель и октябрь. За 7 дождливых дней марта выпало 21,3 мм, это в 2 раза меньше нормы. Основное количество осадков (14,7 мм) поступило за один дождь - с 22 на 23 марта, большей своей частью (86,2\%) пройдя сквозь кроны леса. В еще более сухом (чем март) апреле, за пять дней с осадками выпало 10,5 мм, что в 2,5 раза меньше средней многолетней величины. Лесные кроны пропустили лишь 59,0\% поступившей влаги. Влаги в почве лизиметров стало заметно меньше. Прошедшие 12, 13 и 14 октября дожди были не интенсивны, сквозь кроны леса прошло 46,3\% (8,7 мм) их общего количества (11,4 мм). Выпавшие в конце месяца (30-31 октября) 3,4 мм осадков большей частью были задержаны древесными кронами. В итоге за шесть дней поступило 15,8 мм атмосферной влаги, что в 3,1 раз меньше среднего многолетнего значения для октября. Кроны леса преодолело 10,1 мм (63,9\%).

Почти две декады августа 2017 г. (Зуев, 2017; Летухова, 2017) были не только жаркими, но и сухими. За первую половину месяца прошел один дождь - 15 августа, принесший 0,1 мм атмосферной влаги. А так как ранее последний раз она поступала 19 июня, то в почве наблюдался значительный водный дефицит. Происходило массовое усыхание листвы у древесно-кустарниковой растительности. Велика вероятность отпада значительной ее части. Чрезвычайно обильный и интенсивный грозовой дождь прошел 18-19 августа. Из поступивших 36,3 мм (98,9\% всех августовских осадков, которых оказалось в 1,1 раз меньше среднего многолетнего значения) атмосферной влаги лесные кроны преодолело 34,4 мм. Вес почвы лизиметров возрос почти на величину веса поступившей влаги. До конца месяца был еще один день (23 августа) с небольшими (0,3 мм) осадками, которые полог леса полностью удержал. Период жары и засухи захватил и сентябрь. Количество почвенной влаги лизиметров уменьшилось почти до наименьшей годовой величины, зафиксированной перед ливнем, выпавшим 18-19 августа. Первый и единственный за месяц дождь прошел 23 сентября. Из выпавших 16,8 мм (в 2,4 раза меньше средней многолетней величины) кроны леса смогло преодолеть 12,7 мм.

Апрель 2018 г. выдался очень сухим, к тому же в конце него - начале мая произошла вспышка численности зеленой дубовой листовертки. Второго апреля выпали слабые осадки величиной 3,8 мм. Очень слабые осадки (до 1 мм) поступили 19 и 20 апреля. В итоге за три дождливых дня выпало 4,7 мм осадков, что в 5,6 раз меньше среднего многолетнего значения. Суше было лишь в апреле 2013 (3,2 мм) и 2009 (0,0 мм) гг. Только 61,7\% осадков смогло преодолеть кроны деревьев. Почва лизиметров потеряла много влаги. С 12 мая по 22 июня было всего четыре дождливых дня, за которые сумма поступлений атмосферной влаги составила 3,5 мм. Кроны леса смогли преодолеть 1,4 мм. Август был очень сухим, суше было лишь в 2008 г., когда в августе осадков вообще не было. Единственный очень слабый дождь (0,3 мм), прошедший 7 августа, был полностью удержан лесными кронами. К концу месяца почва степного лизиметра иссушилась до того, что уменьшение ее веса по прошествии недели едва фиксировалось. 
Таким образом, при частой повторяемости засушливых лет недостаток влаги привел к ослаблению устойчивости лесных фитоценозов, а у отдельных пород и к физиологическим нарушениям. Самый массовый текущий отпад шиповника и терна зафиксирован в 2013. В течение 2014-2018 гг. состояние древесно-кустарниковых сообществ стационара продолжало ухудшаться. Наиболее массовое усыхание ранее ослабленных деревьев клена и ясеня произошло в 2015 г. и в особенности в последние два года (2017-2018 гг.).

Считается, что роль осенних осадков является определяющей в пополнении запаса влаги корнеобитаемого слоя лесной почвы и непосредственным образом или через изменение других факторов сказывается на жизнеспособности древостоев. Установлена достоверная связь между текущим отпадом стволов, минимумами осадков и максимумами температур воздуха в конце каждого вегетационного периода, особенно с сентябрьскими показателями (Рыжков, Рыжкова, 2000). На КЛЭС за 2012-2016 гг. количество осадков в осенний сезон снизилось по сравнению с периодом 2000-2011 гг. с 157,9 до 100,6 мм (при уменьшении числа дождливых дней с 21 до 16). Наибольшая убыль поступлений атмосферной влаги наблюдалась в ноябре - с 59,4 до 26,7 мм. Можно предположить, что в водной составляющей устойчивого состояния лесных насаждений Юго-Восточного Крыма наиболее значимыми осадками являются ноябрьские. Летние дожди, хотя их величина за последние годы и возросла на 41,9 мм, неспособны в силу своего ливневого характера и редкости поступления на фоне повышения температурного режима (а за теплое полугодие (апрель-сентябрь) средняя максимальная температура, полученная из суточных максимальных температурных показателей, возросла на $1,3^{\circ} \mathrm{C}$ ) обеспечивать в лесных насаждениях нормальный водный режим.

В условиях КЛЭС образование поверхностного стока возможно круглогодично. Величина и характер стока зависит от величины и интенсивности осадков, мощности снежного покрова и быстроты снеготаяния, крутизны и длины склона, состояния почвы и растительности. В зависимости от характера выпадения и поступления (в случае с твердыми осадками) осадков при одинаковом либо близком годовом количестве атмосферной влаги формируются совершенно различные объемы поверхностного стока. На юго-восточном склоне балки, покрытом густой травянистой растительностью с куртинами держи-дерева, в нижней части которого установлена стоковая площадка СП3 , сток образуется редко, как правило, в результате сильных ливней. Его объем зависит от соотношений интенсивности осадков и скорости впитывания влаги в почву. За период наблюдений в большинстве случаев сток был вызван ливневыми осадками величиной более 20 мм. При ливнях меньшей величины небольшая крутизна $\left(14^{\circ}\right)$ недлинного (50 м) участка склона и густой травостой обычно не позволяют образоваться поверхностному стоку. Исключение составляет формирование стока в связи с относительно небольшими (10-15 мм), но чрезвычайно интенсивными осадками. На формирование поверхностного стока на СП-1 существенное влияние оказывает растущий над и на ней дубовограбинниковый лес. Проникающие под полог лесного сообщества воды ливневых осадков благодаря лесной подстилке, выполняющей роль фильтра, предохраняющего почву от заиливания, и большой водопроводности лесной почвы быстро впитываются. Поэтому поверхностный сток за исключением случаев, связанных с ливнями разрушительной силы, может формироваться лишь в пределах находящегося на стоковой площадки небольшого безлесного пространства. Совершенно другая ситуация складывается над СП-1 в холодное время года при выпадении значительного количества твердых осадков. В результате ветрового переноса здесь скапливается большое количество снега. В случае резкого потепления происходит быстрое таяние снега, образующаяся вода не успевает проникнуть в почву, поверхностный сток принимает достаточно крупные размеры и заметно превосходит его расход на СП-3. Заметное влияние на характер стока оказывает воздействие животных (дикого кабана) на почву, 
состав и продуктивность растительного покрова. В периоды, когда значительная часть СП-3 была перерыта кабанами, и поступающая от осадков вода значительной частью впитывалась в почву, сток на ней был куда меньше, чем на СП-1. За период исследований самый большой сток $(1,2100$ л/м² $)$ на СП-1 наблюдался 1 марта 2007 г. Его формирование было вызвано таянием выпавшего за неделю до этого двадцати сантиметрового слоя снега. Как в большинстве других случаях образования стока от снега после выпадения твердых осадков до их активного таяния в результате ветрового воздействия произошло перераспределение снега с левого на правый склон балки. На СП-3 наибольшее за 20002018 гг. количество стоковых вод $(1,7200$ л/м²) зафиксировано в необычайно влажный период, длившийся с августа по октябрь 2002 г., после стока, произошедшего там 16 сентября, вызванного выпавшими с 14 по 16 сентября ливневыми осадками величиной 93,8 мм. Наиболее слабое стоковое явление $(0,0025$ л/м²) на СП-1, отмеченное 19 февраля 2009 г., возникло вследствие небольшого (16,1 мм) поступления атмосферной влаги, через два дня после предыдущего случая стока. Минимальное стекание по склону $\left(0,0010\right.$ л/м $\left.{ }^{2}\right)$ на СП-3 за все годы наблюдений произошло 7 июля 2012 г.. Столь малый объём стока (на СП-1 он был в 7 раз больше), при поступлении 26,1 мм атмосферных осадков, обусловлен кабаньем воздействием на поверхность стоковой площадки.

В среднем количество стоковых вод с $1 \mathrm{M}^{2}$ при близкой величине стокообразующих осадков за 2012-2018 гг. оказалась меньше, чем за период 20002011 гг., на СП-1 в 3,1, на СП-3 в 2,6 раз (табл. 5). Величина стока уменьшилась, прежде всего, из-за роста и увеличения деятельной поверхности крон древесной и кустарниковой растительности (на СП-1 из-за растущего над и рядом с ней дубовограбинникового леса и поднявшихся на самой площадки молодых деревьев дуба и граба, а также вследствие формирования на ней лесной подстилки; на СП-3 из-за разросшихся кустов и примыкающих к ней куртин держи-дерева). На площадках добавилось в среднем по одному случаю возникновения стока.

Характеристика поверхностного стока 2000-2018 гг.

\begin{tabular}{|c|c|c|c|c|}
\hline $\begin{array}{c}\text { № стоковой } \\
\text { площадки }\end{array}$ & Значение & $\begin{array}{c}\text { Сток за дождь, } \\
\text { л/м² (раз) }\end{array}$ & $\begin{array}{c}\text { Число случаев } \\
\text { за год, шт. }\end{array}$ & $\begin{array}{c}\text { Стокообразующие } \\
\text { осадки, мм. }\end{array}$ \\
\hline \multicolumn{5}{|c|}{ Сток 2000-2011 гг. } \\
\hline \multirow{3}{*}{ СП-1 } & Среднее & 0,1270 & 6 & 28,6 \\
\hline & Минимальное & 0,0025 & 0 & 7,1 \\
\hline & Максимальное & 1,2100 & 13 & 119,9 \\
\hline \multirow{3}{*}{ СП-3 } & Среднее & 0,1094 & 6 & 30,4 \\
\hline & Минимальное & 0,0020 & 1 & 7,8 \\
\hline & Максимальное & 1,7200 & 13 & 119,9 \\
\hline \multicolumn{5}{|c|}{ Сток 2012-2018 гг. } \\
\hline \multirow{3}{*}{ СП-1 } & Среднее & 0,0410 & 7 & 34,9 \\
\hline & Минимальное & 0,0030 & 5 & 10,1 \\
\hline & Максимальное & 0,3680 & 13 & 103,2 \\
\hline \multirow{3}{*}{$\mathrm{C} \Pi-3$} & Среднее & 0,0418 & 7 & 35,1 \\
\hline & Минимальное & 0,0010 & 3 & 10,1 \\
\hline & Максимальное & 0,3412 & 12 & 103,2 \\
\hline
\end{tabular}

Из-за повышения температурного режима количество твердых осадков уменьшилось с 11,2 до 7,2\% от годовой суммы атмосферной влаги, а общая продолжительность залегания снежного покрова с учетом минимальной степени покрытия сократилось с 24 до 16 дней. Стало нормой, что с момента выпадения снега и до его схода проходит 0,5-3 дня. Твердые осадки не успевают накапливаться. В результате количество случаев стоковых явлений, вызванных таянием снега, возросла. За период 2000-2011 гг. из 68 случаев стока на СП-1 6 вызваны сходом снега; в 2012-2018 гг. из 50 случаев 
образования стока на СП-1 7 произошли вследствие снеготаяния, следовательно, в условиях этой СП количество случаев за год увеличилось с 0,5 до 0,9. На СП-3 частота стока от таяния снега увеличилась с 0,5 до 0,7 случая за год: за 2000-2011 гг. - 6 из 74; за 2012-2018 гг. -5 из 48. Но при этом из-за уменьшения общего количества твердых осадков и из-за изменения лесом и шибляком условий формирования стока, количество влаги за случай стока заметно уменьшилось. Таким образом, повышение температуры, увеличение числа случаев формирования стока, снижение объёма твердых осадков и быстрый переход их в сток уменьшили количество влаги доступной растениям.

Изменение влажности почвы зависит от величин поступления осадков и непосредственного испарения, которое, в свою очередь, определяется радиационным и тепловым режимами, силой ветра и влажностью воздуха. Растительные сообщества поразному воздействуют на концентрацию и распределение влаги в почве. Верхний почвенный слой под степной растительностью и одиночно стоящими деревьями иссушается быстрее и сильнее, чем под лесными сообществами. В лесу наблюдаемый слой почвы, прикрытый подстилкой, защищенный кронами деревьев и в то же время практически свободный от древесных корней в течение всего года более влажный по сравнению с такими же почвенными слоями безлесного пространства. В наиболее жаркое и сухое время года содержание влаги в верхнем слое почвы под одиночно стоящими деревьями на 3-8\% выше, чем под степной растительностью. В этот же период в степных сообществах, граничащих с лесом, благодаря оттеняющей деятельности последнего в почве сохраняется больше влаги, чем в большинстве других степных участков. За все годы наблюдения наибольшее (в среднем по сообществам 38,1\%) количество влаги в наблюдаемом слое почвы отмечено в феврале 2006 г. В январефеврале этого года из-за необычайно сильных морозов и при невысоком снежном покрове земля глубоко промерзла. После потепления образовавшаяся в результате таяния снега влага не имела возможности передвигаться из верхнего размороженного слоя почвы в нижние все еще находящиеся в замороженном состоянии. В это время на снегозадерживающих участках, расположенных рядом с лесом запас влаги в наблюдаемом почвенном слое был почти таким же большим, как и в лесных массивах. На юго-восточном склоне (точки $25,26,27)$, где в результате ветрового переноса к моменту потепления снега осталось немного, почвенной влаги было меньше, чем в других аналогичных сообществах. Минимальное содержание почвенной влаги (в среднем по растительным группировкам 7,1\%) зафиксировано в 2015 г. В сухом июле в растительных сообществах полевая влажность почвы уменьшилась в 1,3 раза по сравнению с июнем и оказалась в 1,3 раза меньше средней многолетней для июля. Большинство дней августа тоже были без дождей. Влаги в наблюдаемом почвенном слое в среднем по растительным сообществам стало меньше, чем в предыдущем месяце в 1,5 раз и оказалось в 1,7 раз меньше среднего многолетнего августовского значения. Почва оказалась самой сухой с начала наблюдений (с 1998 г.). В петрофитной степи влаги было в 1,3 раза меньше абсолютного минимального значения, отмеченного в августе 2014 г. На большинстве других степных участков влаги было в 1,1 раз меньше минимума, учтенного в августе 2001 г. Влажность почвы в степи, прилегающей к лесу, оказалась равна абсолютному ее минимуму, который был отмечен в августе 2014 года. Под одиночно расположенными деревьями почвенной влаги было в 1,2 раза меньше, чем в августе 2001 г., когда в этих сообществах было отмечено минимальное ее содержание. Лишь в лесу влажность почвы оказалась в 1,1 раз больше абсолютного минимального значения, зафиксированного здесь в августе 2001 г.. Тенденция к уменьшению увлажненности территории КЛЭС не прекращается. Наибольший дефицит почвенной влаги в 2017 г. наблюдался в августе: ее было меньше среднего многолетнего августовского значения в 1,6 раз (суше было лишь в августе 2015 г.). А в сухой и жаркий июнь 2018 г. полевая влажность почвы оказалась от 1,7 (под одиночными деревьями и в лесу) до 2,4 (в 
петрофитной степи) раз меньше своей средней многолетней величины и наименьшей июньской за всё время наблюдений.

За 2012-2018 гг. годовое содержание влаги в исследуемом горизонте почвы в среднем по всем растительным сообществам оказалось меньше средней многолетней величины в 1,2 раза (табл. 6).

Таблица 6.

Полевая влажность почвы (\%) 1998-2018 гг.



Более всего (в 1,3 раза) ее уменьшилось в почве петрофитной степи. Под одиночными деревьями и в лесу убыль почвенной влаги оказалась наименьшей (в 1,1 раз). Только в июне влаги в почве стало больше, причем с небольшой разницей (в 1,04 раза) и не по всем растительным группировкам. Несмотря на то, что гидротермический коэффициент Селянинова, характеризующий условия увлажнения территории в вегетационный период (апрель - октябрь), не изменился и по-прежнему 
равняется 0,7 единицам, прослеживается явное уменьшение количества воды в почвенном слое наиболее важном для большинства видов травянистой растительности, самосева и подроста древесно-кустарниковой растительности. В апреле и с августа по октябрь гидротермический коэффициент (ГТК) в среднем уменьшился с 0,9 до 0,6 (табл. 7). А с мая по июль произошло его увеличение на 0,3 единицы. В целом этот показатель (ГТК) аридности не вполне объективно отражает степень обеспеченности растительности влагой. За продолжительный временной промежуток рассматривается общее количество выпадающих осадков без учёта частоты их поступлений. При обильных ливнях, чередующихся с продолжительными засухами, коэффициент Селянинова может быть достаточно высоким. Однако в большинстве дней в корнеобитаемом почвенном слое наблюдается недостаточное количество влаги для нормального роста и развития растений. Так, например, за июнь 2015 г. за шесть дождей поступило 61,5 мм, что почти соответствует средней многолетней величине (на 2,1 мм больше). Месячная сумма активных температур составила $647,4^{\circ} \mathrm{C}$. Соответственно ГТК за этот месяц равнялся 1,0 . При этом большая часть количественного поступления атмосферных осадков (46,8 мм) пришлась на начало месяца (5 июня). Благодаря значительному повышению температурного режима и отсутствию новых поступлений осадков к середине месяца влаги в наблюдаемом почвенном горизонте оказалось в 1,3 раза меньше среднего многолетнего июньского значения.

Гидротермический коэффициент (ед.) 2000-2018 гг.

\begin{tabular}{|c|c|c|c|c|c|c|c|c|}
\hline \multirow{2}{*}{ Показатель } & \multicolumn{1}{|c|}{ Месяц } & \multirow{2}{*}{ За вегетационный период } \\
\cline { 2 - 7 } & 4 & 5 & 6 & 7 & 8 & 9 & 10 & \multirow{2}{*}{ Гидротермический коэффициент (ед.) 2000-2011 гг. } \\
\hline Осадки & 28,8 & 29,0 & 42,3 & 28,5 & 43,7 & 46,5 & 52,0 & 270,8 \\
\hline САТ & 199,5 & 470,2 & 612,0 & 746,8 & 744,7 & 562,9 & 342,0 & 3678,0 \\
\hline ГТК & 2,0 & 0,7 & 0,7 & 0,4 & 0,6 & 0,8 & 1,7 & 0,7 \\
\hline \multicolumn{10}{|c|}{ Гидротермический коэффициент (ед.) 2012-2018 гг. } \\
\hline Осадки & 18,5 & 39,2 & 91,8 & 36,8 & 27,8 & 35,7 & 38,2 & 288,0 \\
\hline САТ & 255,4 & 540,0 & 655,7 & 760,6 & 791,7 & 585,9 & 336,9 & 3926,1 \\
\hline ГТК & 1,1 & 0,8 & 1,4 & 0,5 & 0,4 & 0,6 & 1,3 & 0,7 \\
\hline
\end{tabular}

За годы наблюдений естественным образом выделились два периода различных по динамике уровня грунтовых вод (Зуев, 2017б). В первый из них, занявший 19952011 гг, атмосферные осадки непосредственно не влияли на колебание уровня грунтовых вод. После выпадения значительных осадков и до подъема уровня воды в смотровом колодце, используемом в качестве пункта наблюдений за грунтовыми водами, проходило несколько месяцев, а иногда и лет. Однако спад уровня по времени занимал не более 1030 дней (с 22 мая 2006 г. по 16 марта 2009 г.). Поднятие уровня, как правило, происходило резко и на большую высоту - до 3,225 м (между 6 и 13 января 1997 г.). При этом обычно наблюдалось и понижение температуры воды на $1-2^{\circ} \mathrm{C}$. Самый высокий уровень (1,115 м) в колодце отмечен 7 апреля 1997 г. В 1996 г. колодец пересыхал. Пересохшим колодец оставался 180 дней (с 30 января по 29 июля). В редкое время, когда грунтовые воды находились высоко, происходила постоянная их подпитка за счет поступающих осадков, на которые уровень тут же реагировал повышением. Начало нынешнего особо депрессивного периода состояния грунтовых вод пришлось на февраль 2011 г. Тогда начавшееся опускание уровня воды в колодце продолжалось в 2012-2016 гг. Совсем небольшое (на 5 мм) поднятие воды в колодце зафиксировано в самом конце необычайно дождливого мая 2016 г. В начале июня того же года после поступления еще более обильных ливневых осадков уровень поднялся еще на 35 мм. Скорее всего, как и в предыдущие годы в подобных случаях атмосферная влага попала сверху под кольцо колодца. Далее уровень грунтовых вод продолжал опускаться, пока в начале ноября 
2016 г. колодец не пересох, и в настоящее время остается пересохшим. Столь длительное депрессивное состояние уровня грунтовых вод свидетельствует о вероятном изменении гидрологических условий, что косвенно подтверждается фактом уменьшения расхода воды в источнике Чобан-Чокрак, расположенном на склоне хребта в 500 м от и на 110 м выше месторасположения колодца. По сравнению с периодом 1995-2011 гг. среднегодовой дебит источника в 2011-2018 гг. уменьшился в 7,9 раз при уменьшении количества атмосферной влаги всего на 33,7 мм и увеличении среднегодовой температуры воздуха на $0,8^{\circ} \mathrm{C}$ (табл. 8). Пока колодец не пересох, температура воды в нем изменялась плавно, параллельно изменению температурного режима воздуха. При этом как понижение, так и повышение температуры воды колодца по сравнению с температурой воздуха запаздывало по мере охлаждения или прогревания водоносных слоев. В среднем температура колодезной воды за годы наблюдений составила $11,2^{\circ} \mathrm{C}$. Наиболее низкой $\left(1,9^{\circ} \mathrm{C}\right)$ температура воды, которой в колодце к тому времени почти не осталось, была 23 января 1996 г. накануне полного его пересыхания. Максимальная температура 15,5 $\mathrm{C}$ зафиксирована 3 августа 1998 и 27 сентября 2010 гг.

Таблица 8.

Средние и абсолютные многолетние значения уровня, дебита и температуры грунтовых вод

\begin{tabular}{|c|c|c|c|c|c|c|c|c|c|}
\hline \multirow[b]{2}{*}{ 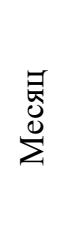 } & \multirow[b]{2}{*}{ 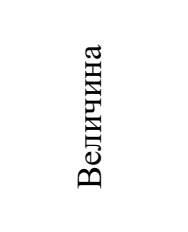 } & \multirow[b]{2}{*}{ 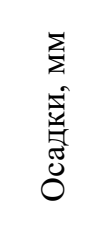 } & \multirow[b]{2}{*}{ 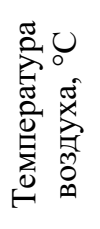 } & \multicolumn{2}{|c|}{ Колодец } & \multicolumn{2}{|c|}{ Источник С/Ю } & \multicolumn{2}{|c|}{ Источник Л/Л } \\
\hline & & & & 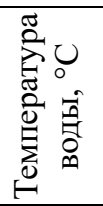 & 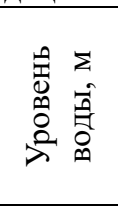 & 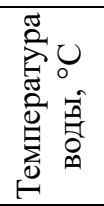 & 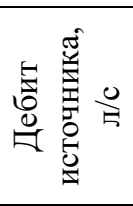 & 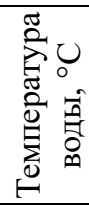 & 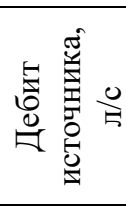 \\
\hline \multicolumn{10}{|c|}{ Грунтовые воды 1995/2007-2011 гг. } \\
\hline \multirow{3}{*}{ 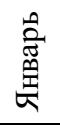 } & Средняя & 39,4 & 1,7 & 8,6 & $-2,840$ & 11,9 & 0,2200 & 14,8 & 0,00493 \\
\hline & Минимум & 13,1 & $-24,0$ & 1,9 & $-4,768$ & 9,5 & 0,0100 & 13,5 & 0,00363 \\
\hline & Максимум & 106,4 & 15,4 & 11,5 & $-1,227$ & 13,2 & 1,1550 & 17,1 & 0,00957 \\
\hline \multirow{3}{*}{ 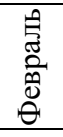 } & Средняя & 42,5 & 2,0 & 7,9 & $-2,629$ & 11,8 & 0,2458 & 14,7 & 0,00572 \\
\hline & Минимум & 3,8 & $-15,8$ & 3,2 & $-4,241$ & 9,1 & 0,0110 & 12,4 & 0,00363 \\
\hline & Максимум & 94,5 & 16,5 & 10,0 & $-1,240$ & 13,1 & 1,0870 & 16,5 & 0,01345 \\
\hline \multirow{3}{*}{$\overline{\bar{\sigma}}_{\bar{\Sigma}}$} & Средняя & 45,1 & 5,0 & 7,8 & $-2,537$ & 12,0 & 0,3011 & 15,2 & 0,00536 \\
\hline & Минимум & 5,5 & $-7,8$ & 3,8 & $-4,210$ & 10,0 & 0,0200 & 13,7 & 0,00385 \\
\hline & Максимум & 113,8 & 21,1 & 9,8 & $-1,215$ & 13,4 & 2,0000 & 16,5 & 0,01012 \\
\hline \multirow{3}{*}{$\begin{array}{l}\text { 竞 } \\
\text { 安 }\end{array}$} & Средняя & 28,8 & 10,1 & 8,7 & $-2,399$ & 12,4 & 0,1933 & 15,5 & 0,00475 \\
\hline & Минимум & 0,0 & $-5,4$ & 4,8 & $-4,200$ & 10,7 & 0,0250 & 14,5 & 0,00415 \\
\hline & Максимум & 59,8 & 24,8 & 10,7 & $-1,115$ & 13,5 & 1,0000 & 16,4 & 0,00603 \\
\hline \multirow{3}{*}{$\sum$} & Средняя & 29,0 & 15,6 & 10,5 & $-2,375$ & 12,8 & 0,1393 & 16,9 & 0,00444 \\
\hline & Минимум & 2,2 & 2,9 & 8,5 & $-4,180$ & 12,1 & 0,0190 & 15,7 & 0,00408 \\
\hline & Максимум & 63,2 & 30,2 & 12,5 & $-1,280$ & 14,0 & 1,7540 & 18,5 & 0,00487 \\
\hline \multirow{3}{*}{ 旪 } & Средняя & 42,3 & 20,4 & 11,8 & $-2,630$ & 13,6 & 0,0544 & 18,7 & 0,00421 \\
\hline & Минимум & 2,7 & 7,1 & 10,3 & $-4,370$ & 12,5 & 0,0150 & 16,5 & 0,00387 \\
\hline & Максимум & 130,7 & 33,7 & 14,5 & $-1,495$ & 16,7 & 0,3080 & 20,0 & 0,00481 \\
\hline \multirow{3}{*}{ 岂 } & Средняя & 28,5 & 24,1 & 12,9 & $-2,845$ & 14,6 & 0,0586 & 20,1 & 0,00408 \\
\hline & Минимум & 0,0 & 11,3 & 11,4 & $-4,710$ & 12,8 & 0,0070 & 18,9 & 0,00372 \\
\hline & Максимум & 67,0 & 37,2 & 15,1 & $-1,795$ & 17,7 & 1,8870 & 21,8 & 0,00511 \\
\hline \multirow{3}{*}{ 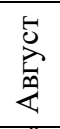 } & Средняя & 43,7 & 24,0 & 13,8 & $-3,092$ & 15,3 & 0,0336 & 20,9 & 0,00388 \\
\hline & Минимум & 0,0 & 11,0 & 12,3 & $-4,790$ & 13,5 & 0,0070 & 19,5 & 0,00359 \\
\hline & Максимум & 173,1 & 38,9 & 15,5 & $-2,305$ & 18,5 & 0,3700 & 22,3 & 0,00455 \\
\hline \multirow{3}{*}{ 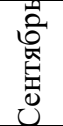 } & Средняя & 46,5 & 18,8 & 14,1 & $-3,181$ & 15,1 & 0,1076 & 20,8 & 0,00375 \\
\hline & Минимум & 5,4 & 7,4 & 12,2 & $-4,750$ & 13,5 & 0,0068 & 18,8 & 0,00344 \\
\hline & Максимум & 134,1 & 32,7 & 15,5 & $-2,535$ & 17,5 & 1,8000 & 22,4 & 0,00443 \\
\hline \multirow{3}{*}{ 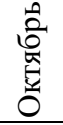 } & Средняя & 52,0 & 12,9 & 13,7 & $-3,173$ & 14,2 & 0,0942 & 19,4 & 0,00404 \\
\hline & Минимум & 5,6 & 0,0 & 10,5 & $-4,720$ & 12,8 & 0,0050 & 17,3 & 0,00354 \\
\hline & Максимум & 133,1 & 27,4 & 15,1 & $-1,425$ & 16,4 & 1,3000 & 21,7 & 0,00571 \\
\hline
\end{tabular}




\begin{tabular}{|c|c|c|c|c|c|c|c|c|c|}
\hline \multirow[b]{2}{*}{ 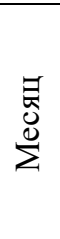 } & \multirow[b]{2}{*}{ 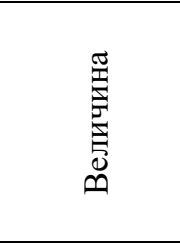 } & \multirow[b]{2}{*}{ 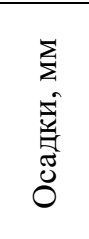 } & \multirow[b]{2}{*}{ 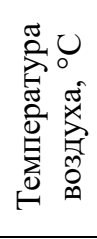 } & \multicolumn{2}{|c|}{ Колодец } & \multicolumn{2}{|c|}{ Источник С/Ю } & \multicolumn{2}{|c|}{ Источник Л/Л } \\
\hline & & & & 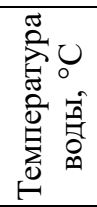 & 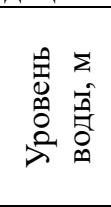 & 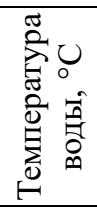 & 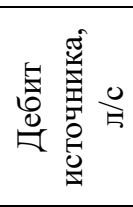 & 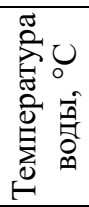 & 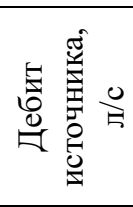 \\
\hline \multirow{3}{*}{ 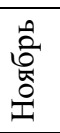 } & Средняя & 59,4 & 8,1 & 12,3 & $-3,138$ & 13,2 & 0,1462 & 17,7 & 0,00507 \\
\hline & Минимум & 1,1 & $-7,7$ & 8,3 & $-4,725$ & 11,5 & 0,0100 & 15,8 & 0,00365 \\
\hline & Максимум & 137,4 & 22,4 & 14,0 & $-1,362$ & 14,5 & 0,9100 & 20,0 & 0,01291 \\
\hline \multirow{3}{*}{ 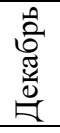 } & Средняя & 43,3 & 3,8 & 10,7 & $-3,156$ & 12,4 & 0,1844 & 15,6 & 0,00537 \\
\hline & Минимум & 3,8 & $-12,7$ & 5,5 & $-4,745$ & 10,0 & 0,0090 & 12,0 & 0,00355 \\
\hline & Максимум & 115,5 & 18,0 & 13,4 & $-1,455$ & 13,8 & 1,7540 & 17,5 & 0,01282 \\
\hline \multirow{3}{*}{ 武 } & Сред. Год. & 500,5 & 12,2 & 11,1 & $-2,904$ & 13,3 & 0,1480 & 17,8 & 0,00461 \\
\hline & Минимум & 308,3 & $-24,0$ & 1,9 & $-4,790$ & 9,1 & 0,0050 & 12,0 & 0,00344 \\
\hline & Максимум & 714,5 & 38,9 & 15,5 & $-1,115$ & 18,5 & 2,0000 & 22,4 & 0,01345 \\
\hline \multicolumn{10}{|c|}{ Грунтовые воды 2012-2018 гг. } \\
\hline \multirow{3}{*}{ 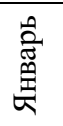 } & Средняя & 51,5 & 2,2 & 9,9 & $-3,758$ & 11,2 & 0,0332 & 14,3 & 0,00321 \\
\hline & Минимум & 32,0 & $-18,4$ & 7,3 & $-4,392$ & 9,8 & 0,0062 & 10,9 & 0,00191 \\
\hline & Максимум & 69,3 & 13,2 & 10,7 & $-3,055$ & 12,3 & 0,1589 & 17,1 & 0,00423 \\
\hline \multirow{3}{*}{ 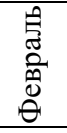 } & Средняя & 31,1 & 2,5 & 8,8 & $-3,783$ & 11,1 & 0,0304 & 14,1 & 0,00328 \\
\hline & Минимум & 15,0 & $-18,5$ & 7,4 & $-4,427$ & 10,0 & 0,0138 & 11,1 & 0,00271 \\
\hline & Максимум & 63,2 & 23,9 & 10,4 & $-3,095$ & 12,2 & 0,0711 & 16,1 & 0,00422 \\
\hline \multirow{3}{*}{$\stackrel{\vec{a}}{\sum_{i}}$} & Средняя & 32,3 & 6,2 & 8,9 & $-3,804$ & 11,2 & 0,0278 & 14,4 & 0,00308 \\
\hline & Минимум & 11,3 & $-5,7$ & 7,5 & $-4,453$ & 10,1 & 0,0118 & 12,4 & 0,00234 \\
\hline & Максимум & 63,9 & 19,8 & 9,8 & $-3,123$ & 12,2 & 0,0680 & 17,8 & 0,00421 \\
\hline \multirow{3}{*}{$\begin{array}{l}\text { 量 } \\
\text { 品 } \\
\text { 是 }\end{array}$} & Средняя & 18,5 & 11,4 & 9,5 & $-3,819$ & 11,9 & 0,0190 & 15,8 & 0,00301 \\
\hline & Минимум & 3,2 & $-2,4$ & 8,0 & $-4,468$ & 11,0 & 0,0107 & 13,9 & 0,00219 \\
\hline & Максимум & 39,7 & 29,7 & 10,5 & $-3,143$ & 12,8 & 0,0305 & 18,4 & 0,00520 \\
\hline \multirow{3}{*}{$\sum$} & Средняя & 39,2 & 17,4 & 10,5 & $-3,836$ & 12,9 & 0,0156 & 17,6 & 0,00290 \\
\hline & Минимум & 4,5 & 6,1 & 9,5 & $-4,487$ & 12,0 & 0,0054 & 15,7 & 0,00207 \\
\hline & Максимум & 122,1 & 30,2 & 11,4 & $-3,154$ & 14,1 & 0,0294 & 19,4 & 0,00434 \\
\hline \multirow{3}{*}{$\begin{array}{l}\text { 突 } \\
\text { 空 }\end{array}$} & Средняя & 91,8 & 21,9 & 11,4 & $-3,835$ & 13,9 & 0,0207 & 18,9 & 0,00423 \\
\hline & Минимум & 24,3 & 10,5 & 10,5 & $-4,453$ & 12,7 & 0,0042 & 17,8 & 0,00199 \\
\hline & Максимум & 212,3 & 34,7 & 12,1 & $-3,173$ & 15,0 & 0,0597 & 21,8 & 0,01165 \\
\hline \multirow{3}{*}{ 昰 } & Средняя & 36,8 & 24,6 & 12,5 & $-3,852$ & 15,1 & 0,0150 & 20,1 & 0,00372 \\
\hline & Минимум & 1,9 & 12,7 & 11,7 & $-4,473$ & 14,1 & 0,0053 & 18,0 & 0,00193 \\
\hline & Максимум & 85,2 & 35,9 & 13,4 & $-3,201$ & 16,8 & 0,0303 & 21,7 & 0,00618 \\
\hline \multirow{3}{*}{ 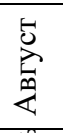 } & Средняя & 27,8 & 25,5 & 13,4 & $-3,914$ & 16,2 & 0,0125 & 21,2 & 0,00334 \\
\hline & Минимум & 0,3 & 12,9 & 12,7 & $-4,578$ & 14,5 & 0,0038 & 19,8 & 0,00194 \\
\hline & Максимум & 76,8 & 38,5 & 14,1 & $-3,263$ & 17,5 & 0,0712 & 22,8 & 0,00461 \\
\hline ठี้ & Средняя & 35,7 & 19,5 & 14,1 & $-3,972$ & 16,0 & 0,0103 & 20,7 & 0,00314 \\
\hline है & Минимум & 1,5 & 7,0 & 13,5 & $-4,605$ & 14,7 & 0,0048 & 17,8 & 0,00187 \\
\hline 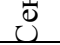 & Максимум & 99,5 & 34,5 & 15,0 & $-3,295$ & 17,5 & 0,0311 & 25,0 & 0,00444 \\
\hline ڤै & Средняя & 38,2 & 12,7 & 13,7 & $-4,006$ & 14,7 & 0,0136 & 19,2 & 0,00310 \\
\hline 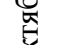 & Минимум & 9,7 & $-1,4$ & 11,2 & $-4,790$ & 12,9 & 0,0059 & 16,5 & 0,00205 \\
\hline 0 & Максимум & 80,8 & 28,4 & 14,9 & $-3,341$ & 16,3 & 0,0371 & 21,5 & 0,00401 \\
\hline 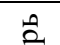 & Средняя & 26,7 & 7,8 & 12,8 & $-3,871$ & 13,4 & 0,0104 & 17,3 & 0,00291 \\
\hline 品 & Минимум & 9,1 & $-5,3$ & 11,8 & $-4,332$ & 11,7 & 0,0067 & 13,2 & 0,00182 \\
\hline 工 & Максимум & 45,7 & 20,9 & 14,3 & $-3,378$ & 15,2 & 0,0203 & 20,0 & 0,00355 \\
\hline : & Средняя & 37,2 & 3,9 & 11,1 & $-3,901$ & 11,9 & 0,0168 & 15,6 & 0,00293 \\
\hline 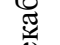 & Минимум & 5,8 & $-9,7$ & 10,0 & $-4,365$ & 10,2 & 0,0063 & 13,5 & 0,00195 \\
\hline$\stackrel{0}{\approx}$ & Максимум & 86,5 & 18,0 & 13,2 & $-3,410$ & 13,8 & 0,0554 & 18,1 & 0,00377 \\
\hline & Сред. Год. & 466,8 & 13,0 & 11,3 & $-3,883$ & 13,3 & 0,0188 & 17,4 & 0,00324 \\
\hline క & Минимум & 349,7 & $-18,5$ & 7,3 & $-4,790$ & 9,8 & 0,0038 & 10,9 & 0,00182 \\
\hline & Максимум & 618,7 & 38,5 & 15,0 & $-3,055$ & 17,5 & 0,1589 & 25,0 & 0,01165 \\
\hline
\end{tabular}

Вследствие понижения уровня грунтовых вод вероятно и произошёл наблюдаемый в последние годы массовый отпад древесно-кустарниковой растительности. Повышение температуры воздуха привело к увеличению естественного 
испарения, а также к возрастанию транспирации у растительности, что неизбежно повлияло на грунтовые воды и могло вызвать падения их уровня. Но скорей всего гидрологические изменения имеют более глубинную первопричину. Известные случаи массовой гибели дубрав связывают с ведущим ключевым фактором, которым считают смену засушливых и влажных периодов, возникающею под влиянием солнечнообусловленных циркуляционных преобразований в атмосфере (Рожков, Козак, 1989). Произрастающая на большей части территорий древесно-кустарниковая растительность использует смешанный способ водного питания (автоморфный и гидроморфный). В относительно влажное время корни растений стационара получают воду в основном за счет поступления влаги от инфильтрации атмосферных осадков. В прежние годы (19982011 гг.) средний уровень грунтовых вод составлял 2,904 м. В продолжительные сухие периоды почвообразующие глинистые отложения, распространенные на большей части КЛЭС, позволяли благодаря капиллярному поднятию влаги над поверхностью грунтовых вод деревьям и кустарникам ее использовать. В период 2012-2018 гг. понижение водоносного горизонта ниже критического уровня в сочетании с длительными, год от года повторяющимися засухами привели к гибели наиболее уязвимых (хотя и отнесенных группе мезоксерофильных) видов кустарников и сильно ослабили древесные ксеромезофиты и даже привели к усыханию некоторых из них. Изменился и состав травянистой растительности стационара. Не встречаются больше такие гигрофиты как: мята длиннолистная (Mentha longifolia (L.) L.), кипрей (Epilobium roseum Schreb.), тростник (Phragmites australis (Cav.) Trin. ex Steud.). Сильно снизилось в составе растительных группировок участие таких мезофитов как: мелисса лекарственная (Melissa officinalis L.), осока Отрубы (Carex otrubae Podp.), щавель курчавый (Rumex crispus L.), ситник Жерара (Juncus gerardii Loisel.). Гораздо реже теперь также можно встретить чесночник черешчатый (Alliaria petiolata (Bieb.) Cavara et Grande), аронник (Arum elongatum Stev.), спаржу (Asparagus verticillatus L.), гравилат городской (Geum urbanum L.), лактук дубравный (Lactuca quercina L.)

Во время сильных осадков растущий над источником Чобан-Чокрак лес препятствует либо резко уменьшает образование поверхностного стока, вследствие этого количество дождевой воды, достигшее водоносного горизонта источника, увеличивается. При достаточной величине атмосферных осадков, поступающих в жидкой форме, дебет источника увеличивается в день выпадения либо в ближайшее за ним время. При температурах воздуха ниже $0^{\circ} \mathrm{C}$, когда выпадают твердые осадки, расход воды в источнике не увеличивается. При таянии большого объема снега дебет родника естественно возрастает. Максимальный за все годы наблюдения расход воды $(2,000$ л/с) в источнике отмечен в начале марта 2007 г. после резкого таяния снега. Даже за последний период с учетом потепления наиболее заметное увеличение разгрузки воды в источнике зачастую связано с твердыми осадками, оно фиксировалось: в 2,8 раз после поступления и таяния в конце января 2014 года обильных снежных осадков; в 2015 году - в середине января в 1,5 раз после таяния снега, в середине третьей декады февраля в 1,3 раза и тоже после снеготаяния; в 1,4 раза - в начале декабря 2016 года после таяния снега; в 2017 году в 2,9 раз 9 января после таяния снега; в 2018 г.: в 4,5 раза 22 января после таяния снега и поступления обильных ливневых осадков, в 2,8 раз 3 декабря вследствие таяния снежного покрова, в этот день в источнике расход воды составил 0,0520 л/с и оказался наибольшим за пять последних лет. Выходит, что хотя в условиях заповедника твердых осадков выпадает немного (в среднем за все годы исследований $11,1 \%$ от общей суммы), но они занимают непропорционально большую часть в том количестве атмосферной влаги, которая после инфильтрации достигает зеркала грунтовых вод. При этом надо учитывать, что в последние годы, как правило, с момента формирования (если температурный режим позволит сформироваться) обычно невысокого снежного покрова до его схода проходит 0,5-3 дня. Повышение температуры 
привело к уменьшению количества снеговых осадков и увеличению их испаряемости, снизив объём талой влаги способной проникнуть до уровня грунтовых вод. Из среднего годового объёма влаги (518,0 мм), поступившей за период 2001-2011 гг., количество твердых осадков, выпавших за 12 дней, составило 57,8 мм (или 11,2\%). В 2013-2018 гг. из 486,3 мм годовых осадков в среднем за 10 снежных дней пришлось 35,1 мм (или 7,2\%). В среднем за 2012-2018 гг. расход источника был в 7,9 раз меньше среднего значения со времени наблюдения (с 1996 по 2011 гг.). Абсолютное снижение дебита $(0,0038$ л/с) отмечено в начале августа 2012 г. в конце жаркого и сухого периода. Водоносные слои находятся близко к поверхности почвы, о чем свидетельствует частое колебание температуры воды источника, которая напрямую зависит от температуры воздуха и температуры инфильтрующих пород. Среднегодовая температура воды в источнике за годы исследования не изменилась и составляет по-прежнему $13,3^{\circ} \mathrm{C}$. В результате уменьшения расхода воды ее различие с температурой воздуха сократились с 1,1 до $0,3^{\circ} \mathrm{C}$. В холодное и прохладное время (с января по апрель и в декабре) вода стала остывать сильней, а в теплую и жаркую пору года ее температура повысилась. Температурный режим воды источника зависит и от температуры поступающих осадков. Так за сентябрьской засухой 2011 г. после череды дождей (с 11 по 19 октября) дебит источника увеличился в 17,4 раза. При этом температура воды источника понизилась сразу на $2,5^{\circ} \mathrm{C}$. Максимальная температура воды источника $\left(18,5^{\circ} \mathrm{C}\right)$ наблюдалась в жаркий и сухой период 2001 г. (20 августа), тогда же в источнике был отмечен минимальный для того года расход воды. Наивысшее температурное значение $2012-2018$ гг. $\left(17,5^{\circ} \mathrm{C}\right)$ фиксировалось дважды. Первый раз в самое сухое и жаркое время 2017 г. - 14 августа, при минимальном годовом дебете $\left(0,0073\right.$ л/с). Точно такая же температура $-17,5^{\circ}$ и тоже на фоне абсолютного снижения дебита $(0,0068$ л/с) в источнике наблюдалось почти через год после продолжительной засухи в начале сентября 2018 г. Абсолютный температурный минимум воды $\left(9,1^{\circ} \mathrm{C}\right)$ в источнике был зафиксирован в конце холодной зимы 2000 г. (28 февраля). Минимальное значение периода 2012-2018 гг. $\left(9,8^{\circ} \mathrm{C}\right)$ температура воды источника имела в начале 2017 г. во время наступления таяния снега.

В продолжительные засушливые периоды относительно стабильное состояние источника Л/Л (весьма медленное уменьшение его разгрузки и ее малозаметное колебание) связано как с инфильтрацией атмосферных осадков, так и с образованием конденсационных вод. Но явление конденсата в источнике носит незначительный характер. Средний дебит источника Л/Л за 2012-2018 гг. составил 0,00324 л/с, это в 1,4 раза меньше среднего значения за 2007-2011 гг., что подтверждает общую динамику происходящих изменений в состоянии грунтовых вод в пределах Карадагской горной группы. Максимальный текущий отпад в насаждениях стационара по времени практически совпал с минимумами разгрузки воды в источнике. Начиная сначала осени 2012 г. в течение десяти месяцев дебит родника Л/Л почти не изменялся, едва заметно уменьшаясь, и к концу мая 2013 г. оказался на тот момент абсолютным минимальным с 2007 г. (0,00242 л/с). Массовое усыхание шиповника и терна произошло осенью 2013 г. В 2017-2018 гг. расход воды источника составил в среднем 0,00249 л/с, это в 1,6 раз меньше средней многолетней величины (рекордный за все время наблюдений минимум расхода воды - 0,00182 л/с в источнике был зафиксирован 27 ноября 2018 г.). Именно в вегетационный период этих лет в лесных сообществах Карадагского заповедника отмечена наибольшая за годы исследований интенсивность отпада ясеня и клена.

\section{Выводы}

За последние годы происходит значительное отклонение основных климатических показателей от средних многолетних значений. Сохраняется тенденция к повышению температуры воздуха. Увеличились средние годовые температуры воздуха 
(в среднем на $0,8^{\circ} \mathrm{C}$ ), с каждым годом изменяются даты начала смены температуры и длительности переходных периодов от одного метеорологического сезона к другому. Минимальная и максимальная годовые температуры воздуха, поверхности почвы и лесной подстилки существенно изменились. Значительное повышение максимальной температуры лесной подстилки в теплое и жаркое время свидетельствует о снижении защитной роли лесного полога, который из-за дефицита атмосферной влаги был вынужден уменьшить свою листовую поверхность и тем самым увеличил доступ солнечной радиации. О том, что кроны деревьев в 2012-2018 гг. стали более ажурными, говорит и сокращение в наблюдаемых средах температурных различий.

Годовое количество осадков уменьшилось на КЛЭС с 500,5 до 466,8 мм. Наблюдается внутригодовое перераспределение атмосферной влаги, связанное, прежде всего, с увеличением объема летних ливневых осадков, причем не за счет увеличения количества дождливых дней, число которых, напротив, за теплое полугодие сократилось, а за счет увеличения в это время поступлений влаги за дождь. Задержание влаги пологом леса уменьшилось при всех градациях осадков из-за ухудшения состояния древесной растительности, обусловленного продолжительными засухами и понижением уровня грунтовых вод.

При частой повторяемости засушливых лет недостаток влаги привел к ослаблению устойчивости насаждений, а у отдельных пород и к физиологическим нарушениям. Наиболее массовый текущий отпад шиповника и терна наблюдался в 2013 г. Наиболее массовое усыхание ранее ослабленных деревьев клена и ясеня произошло в 2015 г. и в особенности в 2017-2018 гг. Из годовых поступлений атмосферной влаги наибольшее влияние на жизнеспособность лесных сообществ КЛЭС оказывает влага, выпадающая в ноябре.

Количество влаги за случай стока заметно уменьшилось, как и из-за уменьшения общего количества твердых осадков, так и из-за изменения лесом и шибляком условий формирования стока.

За 2012-2018 гг. годовое содержание влаги в исследуемом горизонте почвы в среднем по всем растительным сообществам сократилось в 1,2 раза. Прослеживается явное уменьшение количества воды в почвенном слое наиболее важном для большинства видов травянистых растений, самосева и подроста древесно-кустарниковой растительности. Значения гидротермического коэффициента (ГТК) не вполне объективно отражают реальной картины влагообеспеченности растений.

Продолжается многолетний период, начавшийся в феврале 2011 г., с отрицательной динамикой состояния грунтовых вод, негативно отражающейся на растительности. Пересохший в ноябре 2016 г. смотровой колодец, используемый в качестве пункта наблюдений за грунтовыми водами, и в настоящее время продолжает оставаться пересохшим. За 2012-2018 гг. расход источника Чобан-Чокрак был в 7,9 раз меньше среднего значения периода наблюдений 1996-2011 гг. Уменьшение дебита источника Левинсона-Лессинга оказалось несколько более пропорциональным уменьшению количества атмосферных осадков. Его разгрузка сократилась в 1,4 раза, но и это значение подтверждает общую динамику происходящих изменений в состоянии грунтовых вод в пределах Карадагской горной группы.

Повышение температуры привело к уменьшению количества снеговых осадков и увеличению их испаряемости, снизив объём талой влаги способной проникнуть до уровня грунтовых вод.

Наиболее массовый текущий отпад деревьев и кустарников, произошедший в 2013, 2015, 2017 и 2018 гг., связан как с дефицитом влаги в корнеобитаемом почвенном слое, обусловленным засухой, так и с падением грунтовых вод ниже критического для корней растительности уровня. 
Главным причинно-индикаторным гидроклиматическим показателем, отображающим нынешнее состояние растительности, является уровень грунтовых вод, точнее его катастрофическое понижение.

Климатические изменения могут оказаться причиной деградации сложившихся экосистем и привести к смене растительных формаций. Нынешние сукцессионные процессы не являются восстанавливающими и не поддерживают высокий уровень видового разнообразия. Продолжение изменений в растительных сообществах под воздействием быстро меняющихся климатических составляющих скорей всего приведет к обеднению их состава.

\section{Список литературы}

1. Зуев А.В. Карадагский ландшафтно-экологический стационар (КЛЭС) // Летопись природы. Том XXIX. 2012 год. - С. 16-29 (рукопись).

2. Зуев A.B. Карадагский ландшафтно-экологический стационар (КЛЭС) // Летопись природы. Том XXX. 2013 год. - С. 15-40 (рукопись).

3. Зуев A.B. Карадагский ландшафтно-экологический стационар (КЛЭС) // Летопись природы. Том XXXI. 2014 год. - С. 16-42 (рукопись).

4. Зуев А.B. Карадагский ландшафтно-экологический стационар (КЛЭС) // Летопись природы. Том XXXII. 2015 год. - С. 12-41 (рукопись).

5. Зуев А.B. Карадагский ландшафтно-экологический стационар (КЛЭС) // Летопись природы. Том XXXIII. 2016 год. - С. 17-47 (рукопись).

6. Зуев А.В. Карадагский ландшафтно-экологический стационар (КЛЭС) // Летопись природы. Том XXXIV. 2017 год. - С. 12-30 (рукопись).

7. Зуев A.B. Стационарные исследования грунтовых вод на территории Карадагского заповедника // Геополитика и экогеодинамика регионов. - 2017б. - Том 3 (13). Вып. 4. - С. 70-77.

8. Иванов Н.Н. Об определении величины континентальности климата // Изв. Всесоюзного Географического общества. - 1953. - Т. 85. - Вып. 4. - С. 455-457.

9. Ландшафтно-экологический стационар Карадагского природного заповедника. Вып. 1 / под ред. А.Л. Морозовой, Ю.И. Будашкина, В.А. Бокова. - Симферополь: Таврия-Плюс, 1999. - 112 с.

10. Летухова В.Ю. Результаты фенологических наблюдений в Карадагском природном заповеднике // Летопись природы. Том ХХХ. 2013 год. - С. 74-80 (рукопись).

11. Летухова В.Ю. Результаты фенологических наблюдений в Карадагском природном заповеднике // Летопись природы. Том XXXI. 2014 год. - С. 67-74 (рукопись).

12. Летухова В.Ю. Результаты фенологических наблюдений в Карадагском природном заповеднике // Летопись природы. Том XXXIII. 2016 год. - С. 75-83 (рукопись).

13. Летухова В.Ю. Результаты фенологических наблюдений в Карадагском природном заповеднике // Летопись природы. Том XXXIV. 2017 год. - С. 83-117 (рукопись).

14. Природа Карадага / ред. Морозова А.Л., Вронский А.А. - Киев: Наукова думка, 1989. $-256 \mathrm{c}$.

15. Рожков A.A., Козак В.Т. Устойчивость лесов. - М.: Агропромиздат, 1989. - 239 с.

16. Рыжков О.В., Рыжжкова Г.А. Взаимосвязь отпада стволов дуба и древесного опада между собой и с факторами среды // Анализ многолетних данных мониторинга природных экосистем Центрально-Черноземного заповедника: Тр. Центр.Черноземн. гос. заповедника. Тула, 2000. - Вып. 16. - С. 135-143.

17. Сергин С.Я., Яйли Е.А., Цай С.Н., Потехина И.А. Климат и природопользование Краснодарского Причерноморья. - СПб.: изд. РГГМУ, 2001. - 188 с. 
ЗУЕВ А.В., ЛЕТУХОВА В. Ю., ЗУЕВА Е.А.

\section{CLIMATE CHANGE AS A FACTOR OF THE VEGETATION TRANSFORMATION ON THE EXAMPLE OF THE KARADAG LANDSCAPE-ECOLOGICAL STATIONARY \\ Zuev A.V., Letukhova V.Ju., Zueva E.A. \\ T.I. Vyazemsky Karadag Scientific Station-Nature Reserve of RAS - Branch of \\ A.O. Kovalevsky Institute of Biology of the Southern Seas of RAS, \\ Kurortnoe, Feodosia, Russian Federation, \\ email: letukhova@gmail.com}

The current work considers the influence of rapidly changing climatic factors on the viability of individual plant species in conditions of the the Karadag Landscape-Ecological Stationary. It is noted that in recent years there has been a significant deviation of the main climatic data from the long-term averages ones: the average annual, minimum and maximum temperatures of air, as well as of soil surface and forest litter increased, the annual precipitation and the amount of water in the soil layer decreased. This all, in turn, entailed the transformation of vegetation, the mass drying up of certain species of trees and shrubs, the disappearance or number reduction of some hydrophilous forest herbaceous plants in the territory of the Karadag Landscape-Ecological Stationary. It has been determined that among the annual precipitations November downfall has the greatest impact on the state of forest phytocoenosis. It has been besides established that the main cause of the current vegetation state is a catastrophic decrease in the level of groundwater.

Key words: climate, temperature, precipitation, surface run-off, groundwater, change of forest conditions, vegetation's state, Karadag reserve.

Зуев

Александр

Васильевич

Летухова

Виктория

Юрьевна

Зуева

Елизавета

Александровна инженер отдела изучения биоразнообразия и экологического мониторинга, Карадагская научная станция им. Т.И. Вяземского природный заповедник РАН - филиал ФГБУН ФИЦ «Институт биологии южных морей имени А. О. Ковалевского РАН»

кандидат биологических наук, старший научный сотрудник отдела изучения биоразнообразия и экологического мониторинга, Карадагская научная станция им. Т.И. Вяземского - природный заповедник РАН - филиал ФГБУН ФИЦ «Институт биологии южных морей имени А. О. Ковалевского РАН» email: letukhova@gmail.com

лаборант отдела изучения биоразнообразия и экологического мониторинга, Карадагская научная станция им. Т.И. Вяземского природный заповедник РАН - филиал ФГБУН ФИЦ «Институт биологии южных морей имени А. О. Ковалевского РАН»

Поступила в редакцฺию 05.08.2019 г. 